\title{
Paleoseismology of the southern Panamint Valley fault: Implications for regional earthquake occurrence and seismic hazard in southern California
}

\author{
Lee J. McAuliffe, ${ }^{1}$ James F. Dolan, ${ }^{1}$ Eric Kirby, ${ }^{2}$ Chris Rollins, ${ }^{1,3}$ Ben Haravitch, ${ }^{1}$ \\ Steve Alm, ${ }^{4}$ and Tammy M. Rittenour ${ }^{5}$ \\ Received 1 November 2012; revised 23 August 2013; accepted 26 August 2013; published 24 September 2013.
}

[1] Paleoseismologic data from the southern Panamint Valley fault (PVF) reveal evidence of at least four surface ruptures during late Holocene time $(0.33-0.48 \mathrm{ka}, 0.9-3.0 \mathrm{ka}, 3.3-3.6 \mathrm{ka}$, and $>4.1 \mathrm{ka}$ ). These paleo-earthquake ages indicate that the southern PVF has ruptured at least once and possibly twice during the ongoing $(\leq 1.5 \mathrm{ka})$ seismic cluster in the Mojave section of the eastern California shear zone (ECSZ). The most recent event (MRE) on the PVF is also similar in age to the 1872 Owens Valley earthquake and the geomorphically youthful MRE on the Death Valley fault. The timing of the three oldest events at our site shows that the PVF ruptured at least once and possibly thrice during the well-defined 2-5 ka seismic lull in the Mojave section of the ECSZ. Interestingly, the 3.3-3.6 ka age of Event 3 overlaps with the $3.3-3.8 \mathrm{ka}$ age of the penultimate (i.e., pre-1872) rupture on the central Owens Valley fault. These new PVF data support the notion that earthquake occurrence in the ECSZ may be spatially and temporally complex, with earthquake clusters occurring in different regions at different times. Coulomb failure function modeling of the Panamint Valley and Garlock faults reveals significant stress interactions between these two faults that may influence future earthquake occurrence. Specifically, our models suggest a possible rupture sequence whereby an event on the southern Panamint Valley fault can lead to the potential triggering of an event on the Garlock fault, which in turn could trigger the Mojave section of the San Andreas Fault.

Citation: McAuliffe, L. J., J. F. Dolan, E. Kirby, C. Rollins, B. Haravitch, S. Alm, and T. M. Rittenour (2013), Paleoseismology of the southern Panamint Valley fault: Implications for regional earthquake occurrence and seismic hazard in southern California, J. Geophys. Res. Solid Earth, 118, 5126-5146, doi:10.1002/jgrb.50359.

\section{Introduction}

[2] It has long been recognized that seismic moment release is heterogeneous over short time scales. Whereas the most recognizable examples of this are aftershock sequences, a growing body of evidence has begun to show the prevalence of earthquake clusters at a wide variety of spatial and temporal scales over both individual faults and regional fault networks [e.g., Ambraseys, 1971; Marco et al., 1996; Dolan and Wald, 1998; Rockwell et al., 2000; Friedrich et al., 2003; Dawson et al., 2003; Weldon et al., 2004; Ganev et al.,

\footnotetext{
Additional supporting information may be found in the online version of this article.

${ }^{1}$ Department of Earth Sciences, University of Southern California, Los Angeles, California, USA.

${ }^{2}$ Department of Geosciences, Penn State University, University Park, Pennsylvania, USA.

${ }^{3}$ Now at Division of Geological and Planetary Sciences, California Institute of Technology, Pasadena, California, USA.

${ }^{4}$ US Navy Geothermal Program Office, China Lake, California, USA.

${ }^{5}$ Department of Geology, Utah State University, Logan, Utah, USA.

Corresponding author: L. J. McAuliffe, Department of Earth Sciences, University of Southern California, Los Angeles, CA 90089, USA. (lmcaulif@usc.edu)

(C)2013. American Geophysical Union. All Rights Reserved. 2169-9313/13/10.1002/jgrb.50359
}

2010]. The documentation and understanding of these seismic patterns is of great importance for probabilistic seismic hazard assessments as well as a deeper understanding of both geodynamics and earthquake physics.

[3] Located between Death Valley and Owens Valley, Panamint Valley is an extensional basin located within the eastern California shear zone (ECSZ), a N-S belt/zone of right-lateral shear approximately $100 \mathrm{~km}$ wide that accommodates $\sim 25 \%$ of the total relative motion between the North American and Pacific plates [e.g., Dokka and Travis, 1990a; Dixon et al., 1995; Gan et al., 2000; Dixon et al., 2000; Miller et al., 2001; McClusky et al., 2001; Dixon et al., 2003; Bennett et al., 2003]. This zone of distributed deformation, which initiated between 20 and $6 \mathrm{Ma}$ [Dokka and Travis, 1990b], extends northward from near the Salton trough to the Mina Deflection, where it steps $\sim 50 \mathrm{~km}$ eastward and continues northward as the Walker Lane belt (Figure 1a). North of the Garlock fault, right-lateral shear is accommodated primarily by three large strike-slip and oblique-normal fault systems, the Death Valley-Fish Lake Valley, Panamint Valley-Hunter Mountain-Saline Valley, and Airport Lake-Owens Valley-White Mountains fault systems, from east to west (Figure 1a). Geologic slip rate studies of these three fault systems show that north of the Garlock fault and south of the Townes Pass fault (latitude $\sim 36.27^{\circ} \mathrm{N}$ ), 
(a)

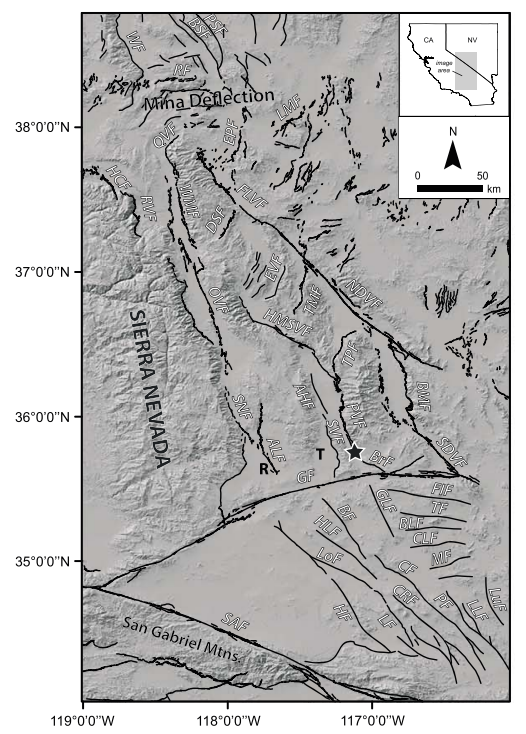

(b)

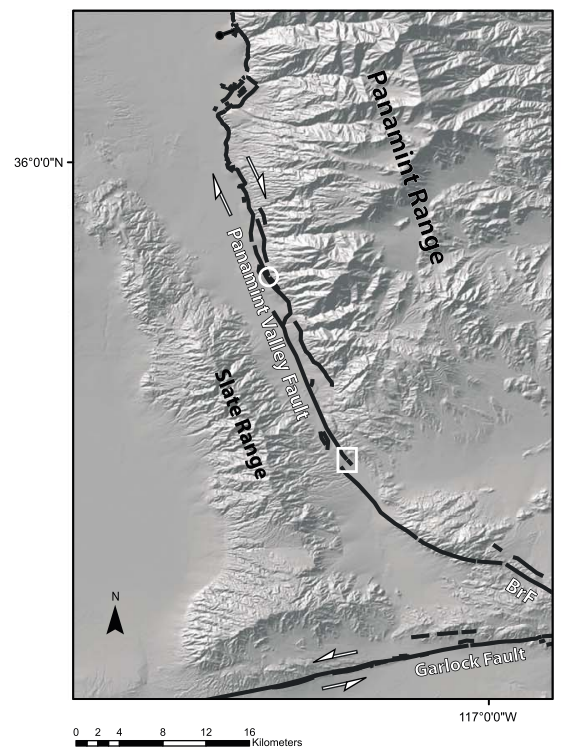

(C)

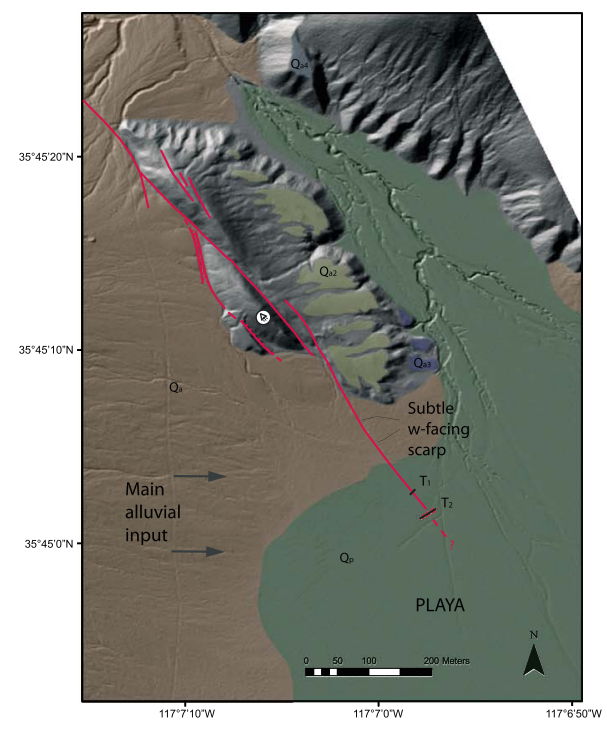

Figure 1. (a) Map showing faults of the ECSZ north and south of the Garlock fault. The black star indicates the location of our trench along the Panamint Valley fault. AHF - Ash Hill fault, ALF - Airport Lake fault, BF - Blackwater fault, BLF - Bicycle Lake fault, BMF - Black Mountain fault, BrF - Brown Mountain fault, BSF - Benton Springs fault, CF - Calico fault, CLF - Coyote Lake fault, CRF - Camp Rock fault, DSF - Deep Springs fault, EPF - Emigrant Peak fault, EVF - Eureka Valley fault, FIF - Fort Irwin fault, FLVF - Fish Lake Valley fault, GF - Garlock fault, GLF - Goldstone Lake fault, HCF - Hilton Creek fault, HF Helendale fault, HLF - Harper Lake fault, HMSVF - Hunter Mountain - Saline Valley fault, LF - Lenwood fault, LLF - Lavic Lake fault, LMF - Lone Mountain fault, LoF - Lockhart fault, LuF - Ludlow fault, MF - Manix fault, NDVF - northern Death Valley fault, OVF - Owens Valley fault, PF - Pisgah fault, PSF - Petrified Springs fault, PVF - Panamint Valley fault, R - Ridgecrest, RF - Rattlesnake Flat fault, RVF - Round Valley fault, SAF - San Andreas fault, SNF - Sierra Nevada frontal fault, SDVF - southern Death Valley fault, SVF - Saline Valley fault, T - Trona, TF - Tiefort Mountain fault, TMF - Tin Mountain fault, TPF Towne Pass fault, QVF - Queen Valley fault, WF - Warm Springs fault, WMF - White Mountains fault. (b) Map showing southern extent of the Panamint Valley fault and central Garlock fault. The Playa Verde trench site is located in the white box (enlarged area in Figure 1c) just east of the Slate Range. White circle indicates slip rate site on the southern Panamint Valley fault [Hoffman et al., 2009]. BrF - Brown Mountain fault. (c) Map of the trench site in southern Panamint Valley, based on GeoEarthScope LiDAR imagery collected in 2008. Enlarged area indicated in Figure 1b. Faults shown in red. Extent of playa deposit shown in green. Active alluvial fans are shown in brown. T-1 and T-2 denote paleoseismologic trenches discussed in this paper. Short red lines on T-2 show locations and trends of major faults exposed in that trench. Qa2, Qa3, and Qa4 are older offset alluvial surfaces. White circle indicates Figure 2 photo vantage point. The coordinates of the trench T-1 end points were $35.75070^{\circ} \mathrm{N}, 117.11626^{\circ} \mathrm{W}$, and $35.75077^{\circ} \mathrm{N}, 117.11619^{\circ} \mathrm{W}$. The end points of trench T-2 were located at $35.75034^{\circ} \mathrm{N}, 117.11609^{\circ} \mathrm{W}$, and $35.75050^{\circ} \mathrm{N}, 117.11584^{\circ} \mathrm{W}$.

the Panamint Valley fault (PVF) has the fastest slip rate $(\geq 1.75-2 \mathrm{~mm} / \mathrm{yr})$ of any fault in the northern part of the ECSZ [Hoffman et al., 2009]; north of the latitude of the Townes Pass fault, strike-slip motion is concentrated primarily on the Death Valley-Fish Lake Valley fault system [Frankel et al., 2007; 2011], with slip transferred northeastward from the Owens Valley-White Mountains fault system and from the Panamint Valley-Hunter Mountain-Saline Valley fault system by way of a series of northeast striking normal and sinistral faults [McKenzie and Jackson, 1986; Oldow et al., 1994; Lee et al., 2001b; Frankel et al., 2011].

[4] Although little is known about the rupture histories of the major ECSZ fault systems north of the Garlock fault, there is an extensive and growing body of work on the paleoseismology of the faults in the Mojave section of the ECSZ south of the Garlock fault. Studies by Rockwell et al.
[2000] and Ganev et al. [2010] on the faults in the Mojave region of the ECSZ have shown that seismic strain release over the past 12,000 years has occurred primarily during clusters of large events. Specifically, paleoseismologic data from several major ECSZ faults documented in Rockwell et al. [2000] reveal earthquake clusters at $\sim 8-9.5 \mathrm{ka}$ and $5-6 \mathrm{ka}$, as well as an ongoing cluster during the past $1.0-1.5 \mathrm{ka}$ that includes the $1992 M_{\mathrm{w}} 7.3$ Landers and $1999 M_{\mathrm{w}} 7.1$ Hector Mine earthquakes. Recent work by Ganev et al. [2010] on the Calico fault, the longest and fastest-slipping fault in the Mojave section of the ECSZ [Oskin et al., 2007], shows that this fault ruptured at least four times during the clusters identified by Rockwell et al. [2000]. These data support the evidence for temporal clustering of earthquakes in the Mojave region.

[5] These results invite an obvious question: Do these earthquake clusters characterize the entire ECSZ, from the 


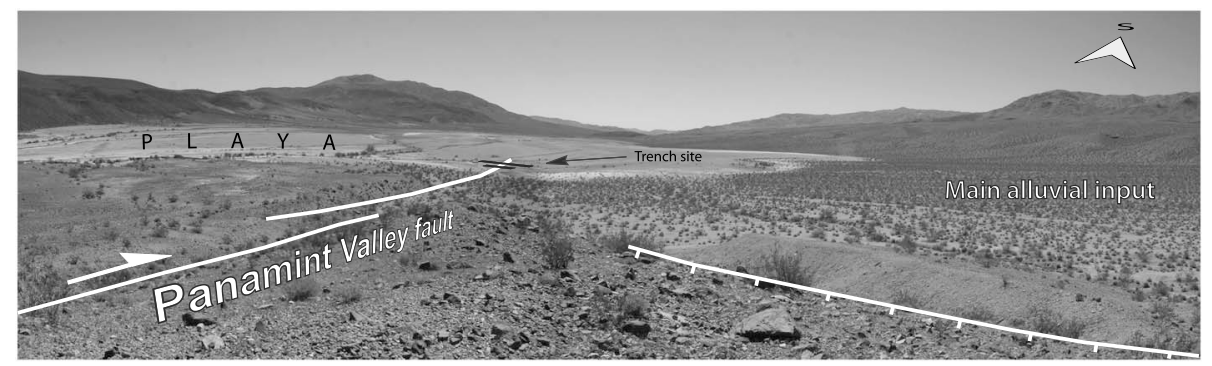

Figure 2. View toward the SSE looking at the playa trench site. The Panamint Valley fault is traced in white together with a down-dropped block formed along a secondary normal fault. Trenches T-1 and $\mathrm{T}-2$ are shown by the black boxes. The main alluvial input from the west is visible in the image.

Mojave northward across the Garlock fault? Or are they a localized phenomenon associated with the structural complexities that mark the individual blocks of the ECSZ? In this paper we describe the results from two trenches excavated across the southern section of the PVF. Radiocarbon dating of charcoal found within key stratigraphic units constrains the ages of the four most recent surface-rupturing earthquakes along this section of the fault. By studying the patterns of seismic strain release along the ECSZ north of the Garlock fault, we can begin to make assessments on the nature of the Garlock fault as a possible structural barrier within the ECSZ.

\subsection{Panamint Valley}

[6] Panamint Valley is thought to have developed since circa $15 \mathrm{Ma}$ along an oblique, west dipping, low-angle detachment fault system (the Emigrant detachment system) that probably linked extension in Panamint Valley with the Death Valley fault zone [Hodges et al., 1989]. Since $4 \mathrm{Ma}$, Panamint Valley has been kinematically linked to dextral strike-slip displacement on the Hunter Mountain fault [Burchfiel et al., 1987; Cichanski, 2000; Walker et al., 2005; Andrew and Walker, 2009]. Consistent with a twostage model for the development of Death Valley area basins, basin extension is thought to have initiated on a low-angle normal fault between $\sim 15$ and $4.2 \mathrm{Ma}$, before switching to the more north-northwest trending Panamint Valley fault zone during the last few million years [Dixon et al., 1995; Reheis and Dixon, 1996, Cichanski, 2000]. Studies of total displacement along the PVF yield values of $9 \pm 1 \mathrm{~km}$ since 4 Ma [Burchfiel et al., 1987] and $\sim 17 \mathrm{~km}$ since the initiation of the basin $\sim 14 \mathrm{Ma}$ [Andrew and Walker, 2009]. The latter offset is based on the reconstruction of the Argus and Panamint Ranges along a displacement vector with an azimuth of $300^{\circ}$, and total dextral slip on the southern PVF is estimated at closer to $10.5 \mathrm{~km}$ [Andrew and Walker, 2009]. Several geologic slip rate studies on the southern PVF indicate a slip rate of $\geq 1.75-2 \mathrm{~mm} / \mathrm{yr}$ [Burchfiel et al., 1987; Zhang et al., 1990; Hoffman et al., 2009].

\subsection{Site Description}

[7] The trench site lies along the southern part of the PVF within the U.S. Navy China Lake Naval Air Weapons Station South Range, $\sim 50 \mathrm{~km}$ east of the town of Ridgecrest, CA (Figure 1a). Through this section of the valley, the fault projects southward into a large $(1 \times 3 \mathrm{~km})$ playa, which we refer to as Playa Verde, within which the fault trace cannot be discerned due to the young sedimentary cover (Figures $1 \mathrm{~b}$ and 1c). We excavated two trenches across the projected fault trace near the northern end of Playa Verde. As a result of annual to decadal resurfacing of the playa with deposition of fine-grained fluvial and lucustrine sediment, no fault scarps are visible on the playa itself. However, geomorphically prominent fault scarps in older alluvium (Unit Qa2) are present directly north of our site (Figure 1c). Although it is clear from field relations that the playa stratigraphy onlaps the coarse gravel alluvium being deposited by the large, active fan to the northwest of the site, in determining our trench locations we needed to balance the likely depth of the base of the playa deposits at the trench site with the requirement that we be able to precisely locate the fault traces beneath the extensive playa.

[8] Although the playa itself is actively aggrading, receiving sediment from the large alluvial fan to the northwest, there is also limited outflow from the playa around the eastern edge of the prominent ridge of uplifted older alluvium that lies due north of our site (Figure 1c). In the area of our trenches the playa outflow channels are only a few centimeters deep, but they become progressively deeper toward the north, and along the eastern edge of the uplifted older alluvium the channels are as much as $1.5 \mathrm{~m}$ deep, with steep to vertical channel walls. These channels are incised into the same playa deposits exposed in our trenches.

\section{Paleoseismic Trenching and Trench Stratigraphy}

[9] In order to determine the exact location of the primary fault strand(s) through the playa, we excavated a preliminary trench close to the northern edge of the playa (Figures 1c and 2). This $12 \mathrm{~m}$ long northern test trench (T-1) was excavated first to locate the fault and to determine the thickness of the playa deposits. Trench T-1 revealed about $2 \mathrm{~m}$ of playa silts and clays overlying coarse-grained, pebble-to-cobble size alluvial gravels deposited by the major fan to the northwest of the site, as well as the locations of several well-defined fault zones (see data repository for photo mosaic of T-1). A 0.5 to $1.0 \mathrm{~m}$ thick, moderately well-developed incipient argillic horizon developed through the thin-bedded playa deposits extended the length of the trench.

[10] Based on the relatively thin stratigraphic section exposed in trench T-1, we excavated a second trench (T-2) approximately $35 \mathrm{~m}$ south of $\mathrm{T}-1$. We used the fault locations from $\mathrm{T}-1$ to guide the location of the $28 \mathrm{~m}$ long trench $\mathrm{T}-2$. As in T-1, trench T-2 revealed a section of thin-bedded playa silts, clays, and minor sands overlying coarse-grained 


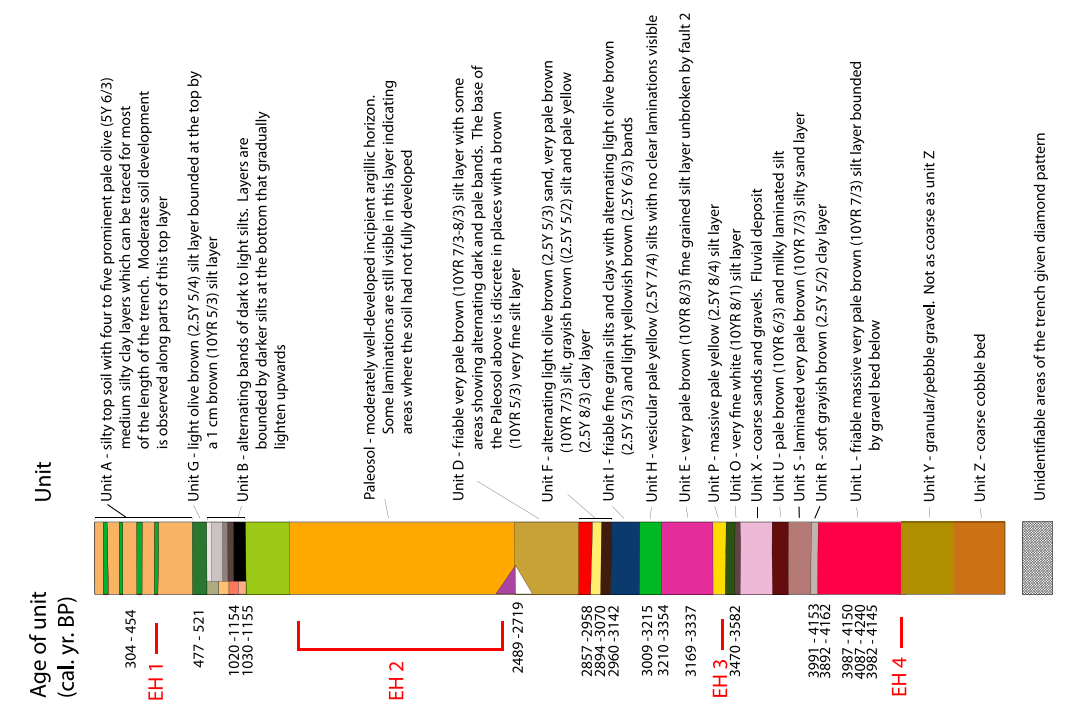

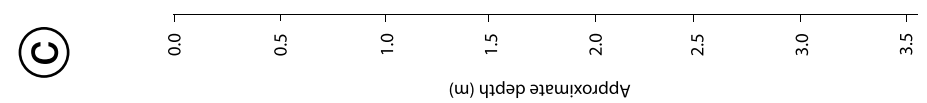
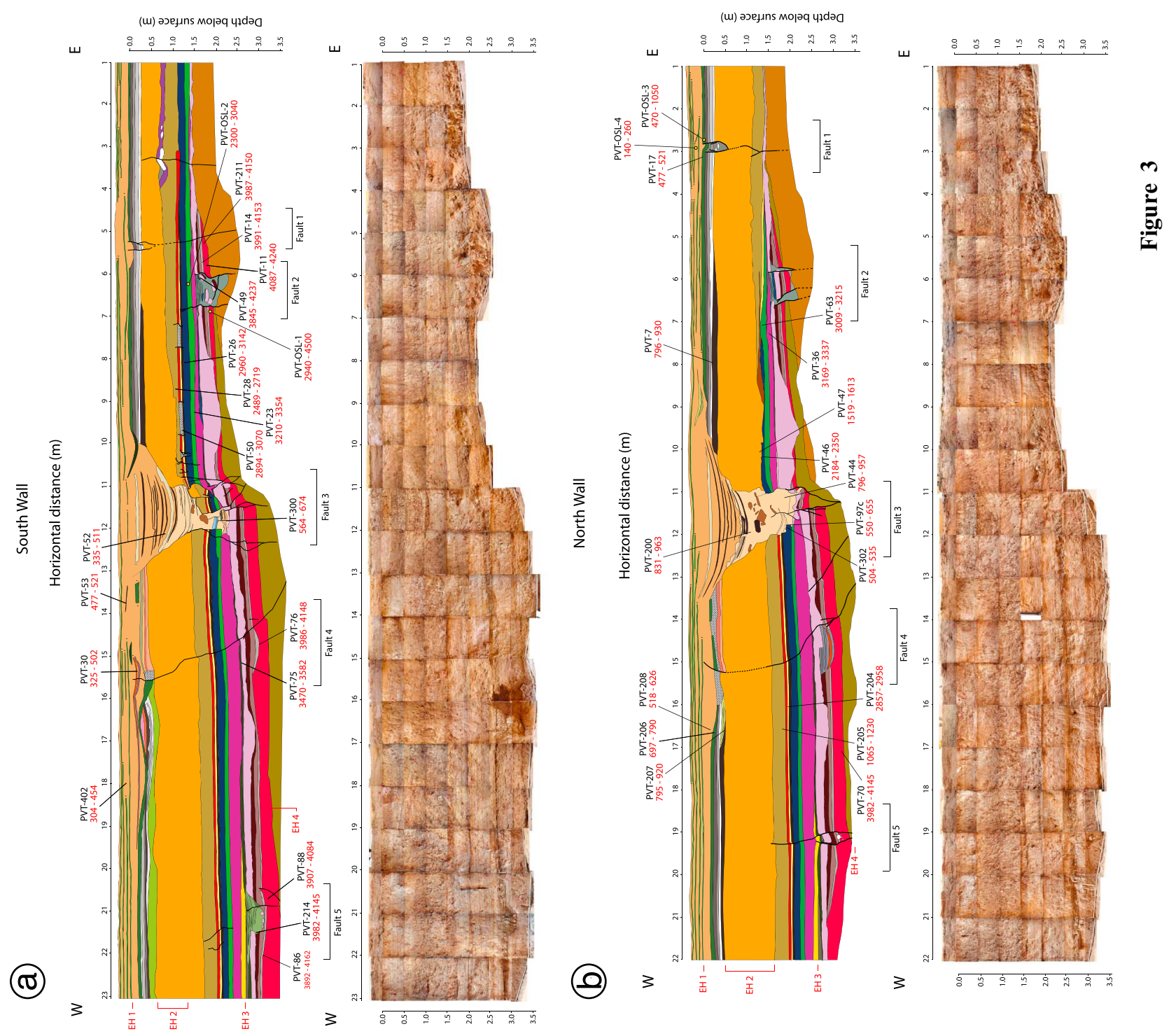
Table 1. Results of Radiocarbon Dating From the Playa Verde Site ${ }^{\mathrm{a}}$

\begin{tabular}{|c|c|c|c|c|c|c|c|c|c|c|c|c|c|}
\hline \multirow[b]{2}{*}{$\begin{array}{l}\text { Sample } \\
\text { number }\end{array}$} & \multirow[b]{2}{*}{$\begin{array}{l}\text { UCI lab } \\
\text { number }\end{array}$} & \multirow[b]{2}{*}{$\begin{array}{l}\text { Altitude } \\
\text { (m asl) }\end{array}$} & \multirow[b]{2}{*}{ Wall } & \multicolumn{8}{|c|}{ Trench Location } & \multicolumn{2}{|c|}{ Sample Age } \\
\hline & & & & $\begin{array}{l}\text { Horizontal } \\
\quad(\mathrm{m})\end{array}$ & $\begin{array}{l}\text { Depth } \\
\text { (m) }\end{array}$ & $\begin{array}{l}\text { Fraction } \\
\text { Modern }\end{array}$ & \pm & $\begin{array}{r}\Delta^{14} \mathrm{C} \\
(\% 0)\end{array}$ & \pm & $\begin{array}{c}{ }^{14} \mathrm{C} \text { Age } \\
\text { (BP) }\end{array}$ & \pm & $\begin{array}{c}\text { OxCal } \\
\text { Calibrated } \\
\text { Age (yr. BP) }\end{array}$ & $\begin{array}{c}\text { OxCal } \\
\text { Trimmed } \\
\text { (Cal. yr. BP) }\end{array}$ \\
\hline PVT-402 & 76742 & 504 & South & 17.85 & 0.22 & 0.9622 & 0.0021 & -37.8 & 2.1 & 310 & 20 & $304-454$ & $302-434$ \\
\hline PVT-30 & 76737 & 504 & South & 15.29 & 0.51 & 0.9545 & 0.0019 & -45.5 & 1.9 & 375 & 20 & $325-502$ & $432-501$ \\
\hline PVT-52 & 76744 & 504 & South & 12.03 & 1.03 & 0.9507 & 0.0019 & -49.3 & 1.9 & 405 & 20 & $335-511$ & N/A \\
\hline PVT-17 & 76736 & 504 & North & 3.10 & 0.30 & 0.9475 & 0.0019 & -52.5 & 1.9 & 435 & 20 & $477-521$ & $480-521$ \\
\hline PVT-53 & 76741 & 504 & South & 13.76 & 0.21 & 0.9475 & 0.0019 & -52.5 & 1.9 & 435 & 20 & $477-521$ & N/A \\
\hline PVT-302 & 85373 & 504 & North & 11.82 & 2.19 & 0.9418 & 0.0023 & -58.2 & 2.3 & 480 & 20 & $504-535$ & N/A \\
\hline PVT-208 & 76740 & 504 & North & 16.72 & 0.62 & 0.9348 & 0.0019 & -65.2 & 1.9 & 540 & 20 & $518-626$ & N/A \\
\hline PVT-97c & 85374 & 504 & North & 11.77 & 2.20 & 0.9263 & 0.0023 & -73.7 & 2.3 & 615 & 25 & $550-655$ & N/A \\
\hline PVT-300 & 85372 & 504 & South & 11.87 & 2.32 & 0.9190 & 0.0022 & -81.0 & 2.2 & 680 & 20 & $564-674$ & N/A \\
\hline PVT-206 & 76738 & 504 & North & 16.75 & 0.62 & 0.8999 & 0.0018 & -100.1 & 1.8 & 845 & 20 & $697-790$ & N/A \\
\hline PVT-7 & 76735 & 504 & North & 7.85 & 0.51 & 0.8871 & 0.0018 & -112.9 & 1.8 & 965 & 20 & $796-930$ & $796-930$ \\
\hline PVT-207 & 76739 & 504 & North & 16.83 & 0.80 & 0.8897 & 0.0018 & -110.3 & 1.8 & 940 & 20 & $795-920$ & 795-919 \\
\hline PVT-44 & 85371 & 504 & North & 11.11 & 2.16 & 0.8846 & 0.0024 & -115.4 & 2.4 & 985 & 25 & $796-957$ & N/A \\
\hline PVT-200 & 76745 & 504 & North & 11.97 & 1.34 & 0.8825 & 0.0018 & -117.5 & 1.8 & 1005 & 20 & $831-963$ & N/A \\
\hline PVT-205 & 85370 & 504 & North & 16.71 & 2.12 & 0.8599 & 0.0021 & -140.1 & 2.1 & 1215 & 20 & $1065-1230$ & N/A \\
\hline PVT-47 & 76757 & 504 & North & 9.99 & 1.59 & 0.8139 & 0.0017 & -186.1 & 1.7 & 1655 & 20 & 1519-1613 & N/A \\
\hline PVT-46 & 76756 & 504 & North & 10.21 & 1.74 & 0.7524 & 0.0015 & -247.6 & 1.5 & 2285 & 20 & $2184-2350$ & N/A \\
\hline PVT-28 & 85369 & 504 & South & 8.51 & 1.35 & 0.7328 & 0.0018 & -267.2 & 1.8 & 2495 & 20 & 2489-2719 & 2489-2719 \\
\hline PVT-204 & 76760 & 504 & North & 16.06 & 2.30 & 0.7052 & 0.0015 & -294.8 & 1.5 & 2805 & 20 & $2857-2958$ & $2857-2957$ \\
\hline PVT-50 & 76758 & 504 & South & 9.62 & 1.55 & 0.6998 & 0.0016 & -300.2 & 1.6 & 2865 & 20 & $2894-3070$ & $2925-3056$ \\
\hline PVT-26 & 76755 & 504 & South & 8.00 & 1.58 & 0.6968 & 0.0014 & -303.2 & 1.4 & 2900 & 20 & $2960-3142$ & $2968-3138$ \\
\hline PVT-63 & 76759 & 504 & North & 6.81 & 1.63 & 0.6924 & 0.0014 & -307.6 & 1.4 & 2955 & 20 & $3009-3215$ & $3071-3211$ \\
\hline PVT-23 & 85376 & 504 & South & 9.18 & 1.82 & 0.6842 & 0.0018 & -315.8 & 1.8 & 3050 & 25 & $3210-3354$ & $3167-3321$ \\
\hline PVT-36 & 85375 & 504 & North & 7.19 & 1.78 & 0.6853 & 0.0017 & -314.7 & 1.7 & 3035 & 20 & $3169-3337$ & $3225-3339$ \\
\hline PVT-75 & 76750 & 504 & South & 15.17 & 2.88 & 0.6628 & 0.0014 & -337.2 & 1.4 & 3305 & 20 & $3470-3582$ & $3471-3586$ \\
\hline PVT-14 & 76747 & 504 & South & 5.70 & 2.04 & 0.6280 & 0.0013 & -372.0 & 1.3 & 3735 & 20 & $3991-4153$ & $3987-4043$ \\
\hline PVT-86 & 76752 & 504 & South & 21.94 & 3.38 & 0.6356 & 0.0014 & -364.4 & 1.4 & 3640 & 20 & $3892-4072$ & $3890-4054$ \\
\hline PVT-76 & 76751 & 504 & South & 14.92 & 3.30 & 0.6293 & 0.0014 & -370.7 & 1.4 & 3720 & 20 & $3986-4148$ & $3984-4047$ \\
\hline PVT-49 & 76748 & 504 & South & 6.05 & 1.90 & 0.6315 & 0.0054 & -368.5 & 5.4 & 3690 & 70 & $3845-4237$ & N/A \\
\hline PVT-211 & 76754 & 504 & South & 5.25 & 1.98 & 0.6291 & 0.0015 & -370.9 & 1.5 & 3725 & 20 & $3987-4150$ & $4011-4150$ \\
\hline PVT-11 & 76746 & 504 & South & 5.71 & 2.06 & 0.6247 & 0.0017 & -375.3 & 1.7 & 3780 & 25 & $4087-4240$ & $4087-4234$ \\
\hline PVT-70 & 76749 & 504 & North & 17.01 & 3.44 & 0.6300 & 0.0013 & -370.0 & 1.3 & 3710 & 20 & $3982-4145$ & $4010-4146$ \\
\hline PVT-214 & 85377 & 504 & South & 21.43 & 3.67 & 0.6302 & 0.0015 & -369.8 & 1.5 & 3710 & 20 & $3982-4145$ & N/A \\
\hline PVT-88 & 76753 & 504 & South & 20.66 & 3.51 & 0.6341 & 0.0013 & -365.9 & 1.3 & 3660 & 20 & $3907-4084$ & $4030-4086$ \\
\hline PVT-403 & 76743 & 504 & South & 20.24 & 0.17 & 1.2539 & 0.0026 & 253.9 & 2.6 & -1815 & 20 & N/A & N/A \\
\hline
\end{tabular}

${ }^{a}$ The charcoal samples received a standard acid-alkali-acid (AAA) pretreatment. All results were corrected for isotopic fractionation according to the conventions of Stuiver and Polach [1977], with $\delta^{13} \mathrm{C}$ values measured on prepared graphite using the AMS. Of the 39 samples sent to the AMS, four samples did not survive the pretreatment and could not be measured.

alluvial gravels deposited by the large fan to the northwest of the site (Figure 3 ). The playa stratigraphy was much thicker in T-2, with a maximum thickness of $\sim 3.6 \mathrm{~m}$ in a structural depression near the central part of the trench. More than 20 layers can be traced the entire length of T-2, and many of these beds can be correlated between trenches T-1 and T-2, attesting to the lateral continuity of strata deposited on the near-horizontal playa surface. The stratigraphic units observed within the two trenches are described in the stratigraphic column (Figure 3c). Trench T-2 exposed the same moderately well-developed, incipient argillic horizon observed in T-1 (Paleosol in Figure 3), indicating this soil is laterally extensive. In T-2, the soil thickens from $40 \mathrm{~cm}$ at the east end of the trench to $1.1 \mathrm{~m}$ in the central and western parts of the trench. Soil development varies, with local areas in which the original playa stratigraphy can be discerned through the soil overprint. Above the argillic horizon, fine-grained playa silts dominate the stratigraphy (Units $\mathrm{A}, \mathrm{B}$, and $\mathrm{G}$ in Figure 3). Below the argillic horizon, the playa sands and silts (Units $\mathrm{H}$ through $\mathrm{L}$ in Figure 3) thin toward the east and onlap onto the underlying coarse-grained alluvial gravels. The well-preserved stratigraphy indicates a lack of

Figure 3. Trench logs of the (a) north and (b) south wall of trench T-2. Charcoal and OSL (yellow circles) samples collected from the trench walls are located on the logs with their calibrated unmodeled ages in years before 1950. Five main fault strands are shown at the base of each log. Photomosaics (shown below the digitized logs) of the south wall and north wall of T-2 show the actual trench wall surface. Due to the slightly undulating surface topography, all depths are recorded from an arbitrary datum $\sim 30 \mathrm{~cm}$ below the surface. Faults are drawn as thick black lines. Grey lines indicate eroded surfaces, and thin black lines indicate fractures or cracks. Colored blocks within the fissure are coherent but unidentifiable units. (c) Composite stratigraphic column of playa units identified in our trenches. Stratigraphic section is representative of thicknesses at meter 20 on south wall of trench; Units $\mathrm{Y}$ and $\mathrm{Z}$ are shown projected schematically at their proper stratigraphic positions. The dates on the left show unmodeled calibrated dates based on charcoal ${ }^{14} \mathrm{C}$ samples collected in each corresponding unit. The bold red lines on the left indicate our four proposed event horizons. Unit color descriptions are based on the Munsell soil color chart. 


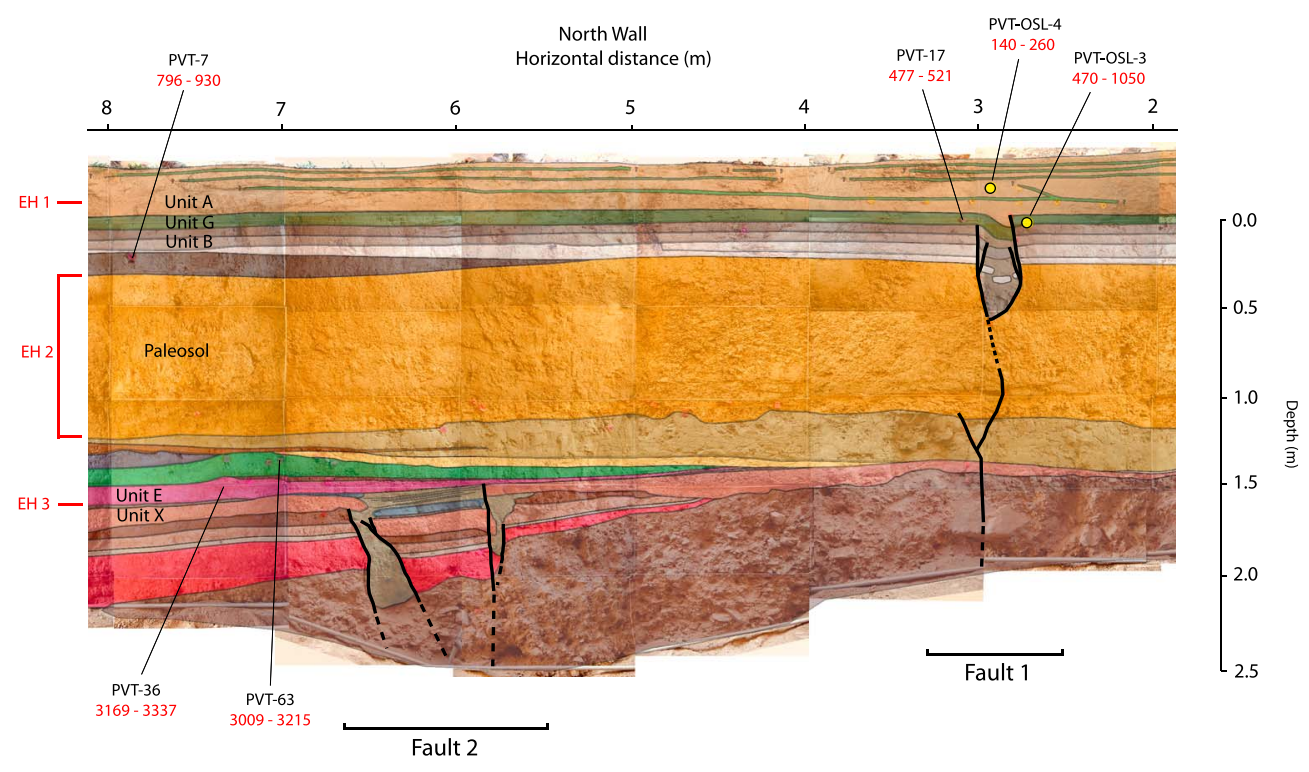

Figure 4. North wall (trench T-2) from meters 2-8. Digital log is draped over the photo mosaic. Faults 1 (meter 3 ) and 2 (meter 6) are clearly identifiable. Event horizons are indicated by red lines on the left.

bioturbation throughout much of the trench (outside of the argillic horizon), likely a result of the frequent inundations of the playa during wet years.

\section{Age Control}

[11] Playa environments commonly provide a favorable location for the accumulation of dateable detrital charcoal, and this was the case at the Playa Verde site. We sampled charcoal fragments from throughout the stratigraphic section exposed in our trench walls, with particularly dense sampling above and below the paleo-earthquake event horizons we identified (discussed below). We submitted 39 samples to the University of California, Irvine, Keck Carbon Cycle accelerator mass spectrometer (AMS) for radiocarbon dating. Radiocarbon ages for the 35 samples that survived pretreatment were calibrated in OxCal v.4.1 [Ramsey, 2001]. Throughout this paper all ages are discussed as calibrated years before present (cal. yr. BP), with "present" defined as 1950 A.D. All ages are expressed at the $95.4 \%$ confidence level. All but one of the radiocarbon samples (PVT-53 was collected from organic rich layer) are detrital charcoal fragments, likely derived from brushfires from the surrounding slopes.

[12] Almost all of the radiocarbon ages are in correct stratigraphic order, with only limited evidence for reworking of the material. Of the 35 radiocarbon dates from trench T-2, only two samples yielded problematic results. Sample PVT403 , which was collected from $27 \mathrm{~cm}$ depth at meter 20 on the south wall, contained excess ${ }^{14} \mathrm{C}$ that most likely came from the mid-twentieth century atmospheric thermonuclear weapons tests. The anomalously young age of this sample relative to other samples from that depth range suggests that it may have been bioturbated into the section. The large uncertainty recorded for sample PVT-49 is due to the very small sample size.

[13] In addition to reporting the calibrated ages in Table 1, in the column following each calibrated sample age we also report refined age estimates based on an OxCal stratigraphic ordering model. The stratigraphic ordering model is used to better constrain the ${ }^{14} \mathrm{C}$ dates for each of the samples. This is done when the stratigraphic sequence is known, allowing for the elimination of some overlapping ages. The OxCal stratigraphic ordering model that was created from the dated samples includes only 20 of the 35 total samples because (a) four samples yielded dates that were slightly older than underlying samples, indicating minor reworking of older carbon (PVT-206, PVT-208, PVT-49, and PVT-214) (Figure 3). Specifically, PVT-206 and PVT-208 seem too old given the age of PVT-17 (from the same Unit G), which was collected from a well-bedded silt layer that did not show any signs of bioturbation, indicating that samples PVT-206 and PVT-208 had significant preburial ages before they were deposited in Units G and A, respectively (Figure 4). Sample PVT-214 from meter 21.5 on the south wall was located in a fissure that we believe opened up in Event 3 (discussed below). The older date of this sample does not fit with the stratigraphy determined by samples PVT- 88 and PVT-86, which lie in undisturbed clay and silt units beneath the fissure (Figure 3); (b) four samples that were much younger than surrounding sediment were likely introduced into the section during bioturbation (PVT-205, PVT-46, PVT-47, and PVT403). As shown with our sediment accumulation rate curve, accepting sample PVT-205 would require extremely high sedimentation accumulation rates during development of the Paleosol (Figure 5). This seems highly unlikely given that development of this cumulate soil likely occurred during periods of slow/intermittent sediment accumulation. Samples PVT-46 and PVT-47 from meter 10 on the north wall were not included in the ordering model because of their proximity to the base of the Paleosol and the resulting uncertainty about the presence or absence of bioturbation in these layers. The patchy and irregular base of the cumulate Paleosol, together with the wide spread of the radiocarbon ages despite their proximity to each other, made it difficult to discern whether PVT-46 is much too old or whether PVT-47 has been bioturbated into the deposit; (c) three samples from Unit A could 
MCAULIFFE ET AL.: PANAMINT VALLEY FAULT PALEOEARTHQUAKES

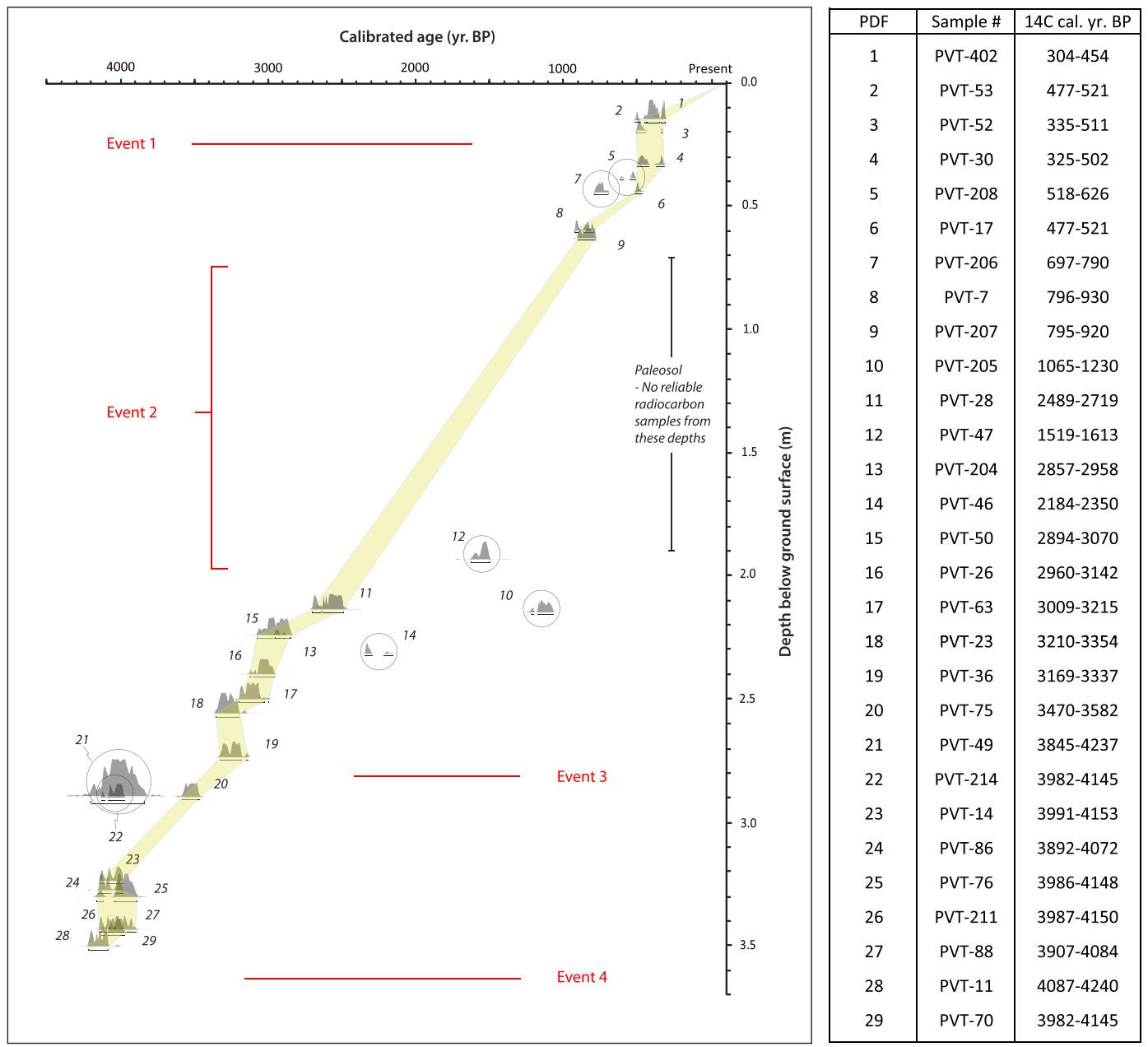

Figure 5. Sediment accumulation rate curve showing probability density functions of OxCal v.4.1 [Ramsey, 2001] unmodeled calibrated calendric radiocarbon ages. The depth below ground surface for each sample has been corrected by projecting all samples to a common reference point (south wall at meter 20 of trench T-2). The green swath encompasses the sediment accumulation rate within the $95.4 \%$ confidence interval. The average sediment accumulation rate of $\sim 0.86 \mathrm{~mm} / \mathrm{yr}$ is based on the depth and age of sample PVT-70. The numbers next to the probability density functions (PDFs) represent the corresponding sample numbers in the adjacent table. The circled PDFs represent samples that we believe either have been reworked and are too old $(21,22,7$, and 5$)$ or have been bioturbated into place and are too young $(10,12$, and 14). The six samples not included in the figure (PVT-44, PVT-97c, PVT-302, PVT-200, PVT-300, and PVT-403) form part of the older colluvial material that fell into the fissure after the MRE. Their exact stratigraphic depth is not known and thus could not be projected to a common reference point.

not be confidently located with respect to the exact event horizon for the most recent event (MRE) (PVT-53, PVT-52, and PVT-208 [sample PVT-208 was also likely bioturbated into the section, as noted above]). Moreover, sample PVT53 was not included in the ordering model because it came from an unusual, $2 \mathrm{~cm}$ thick charcoal-rich layer observed in Unit $\mathrm{A}$ at meter 14 of the south wall from which we took a bulk sample. The age of the material appears too old for its stratigraphic depth, and we decided to rely on dates from larger charcoal samples within well-defined beds with undisturbed upper and lower bedding contacts to minimize the possibility of bioturbation effects; and (d) five samples collected from a large fissure that opened up in the MRE produced dates that were too old or could not be uniquely correlated with strata outside the fissure (PVT-44, PVT- 97c, PVT-302, PVT-200, and PVT-300). An important factor in correctly interpreting charcoal ages at our trench site is that charcoal samples collected from strata filling the large fissure at meters 10 to 13 cannot be used as reliable indicators of the actual ages of those deposits because they were likely at least partially eroded from older stratigraphy in the exposed walls of the large fissure as it was being filled.

[14] Calibrated radiocarbon ages of our samples range from $0.3-0.5 \mathrm{ka}$ to $4.1-4.3 \mathrm{ka}$, indicating that the trenches exposed a mid-late Holocene stratigraphic section (Figure 3 and Table 1). The oldest samples, PVT-11, PVT-211, PVT70, and PVT-88 (OxCal calibrated unmodeled age of $\sim 3892-4240$ cal. yr. BP), were collected from Unit L on the south wall of trench T-2, and the youngest sample, PVT402 (dated at 305-455 cal. yr. BP [OxCal calibrated 
(A)

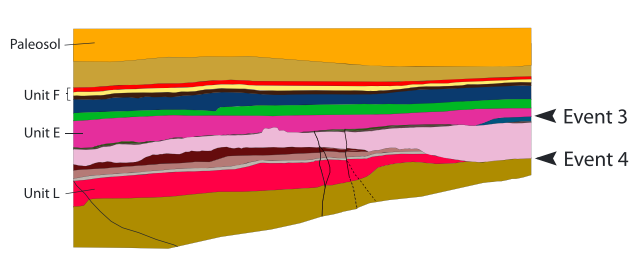

(B)

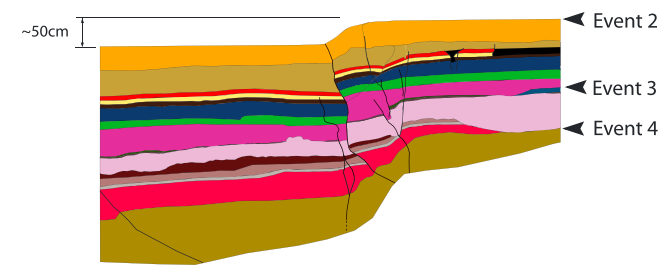

(D)

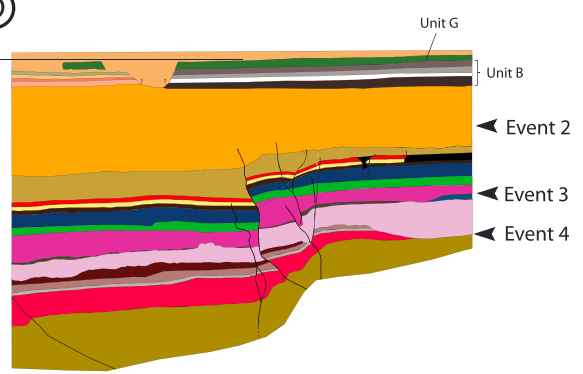

(C)
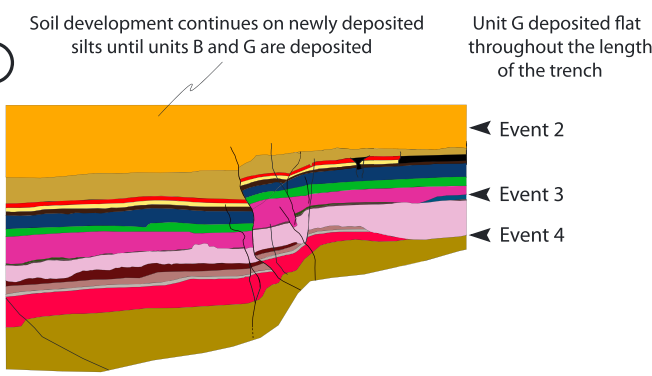
作

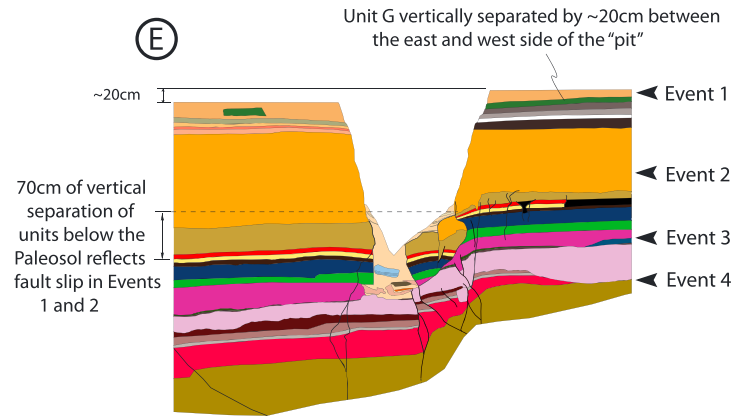

(
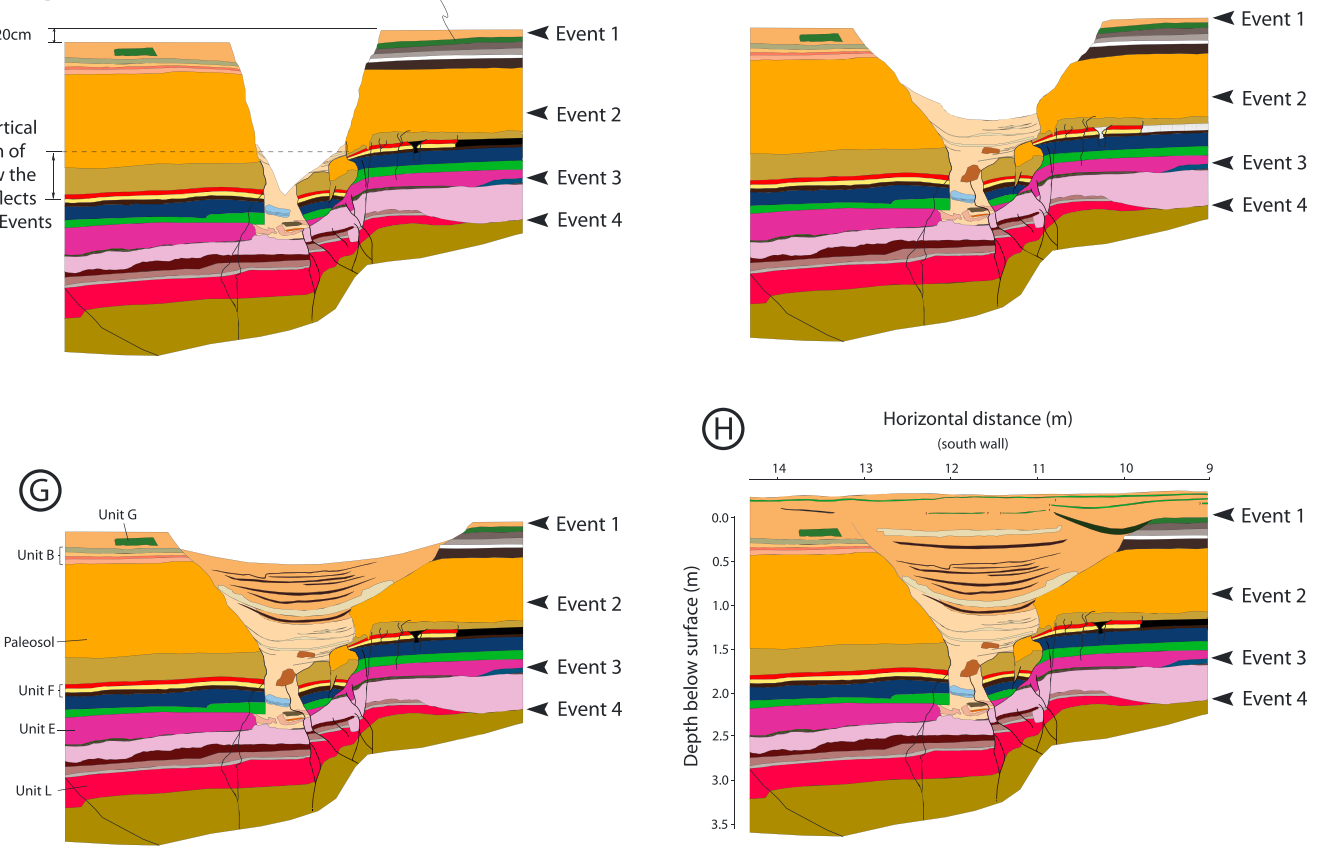

Figure 6. Diagram of the sequential development of stratigraphy across fault strand 3 in the south wall of trench T-2 at meters 9-14 adjacent to the large fissure that formed during the most recent event (MRE). (a) Restoring Units L to F by $\sim 0.7 \mathrm{~m}$ vertically illustrates stratigraphic relationships just prior to Event 2 . Fault strand 3 exhibits little to no deformation during Event 3. Most of the deformation from Event 3 appears to have occurred on fault strands 2 and 4, along which Event 3 is well recorded. Along fault 3 the scarp produced during Event 4 is recorded by a $20-30 \mathrm{~cm}$ step at the base of Unit L. (b) Deformation during Event 2 is characterized by $0.5 \mathrm{~m}$ of vertical separation and the development of an east facing fault scarp. (c) Additional silt may have been deposited across the Event 2 scarp. The Paleosol continued to form incrementally during slow sediment accumulation. (d) Deposition of the units above the Paleosol through Unit G. Unit G is deposited flat throughout the trench. (e) MRE opens up a fissure, and Unit $\mathrm{G}$ now shows $0.2 \mathrm{~m}$ of vertical separation. Units $\mathrm{L}$ to $\mathrm{F}$ are vertically separated a total of $0.7 \mathrm{~m}$. (f) The large fissure is filled in with colluvium from the fissure walls as they erode back. Clays and silts are deposited in the interstices between colluvial blocks in the lowest parts of the fissure fill. Post-earthquake settling may cause small cracks/fractures to form at the base of the fissure. (g) The upper part of the fissure continued to widen during gradual post-MRE collapse and erosion of the walls. The fissure eventually filled completely with stratified silt and clay. Soil began to form within the upper $1 \mathrm{~m}$ of fissure silts. (h) Current trench stratigraphy. 


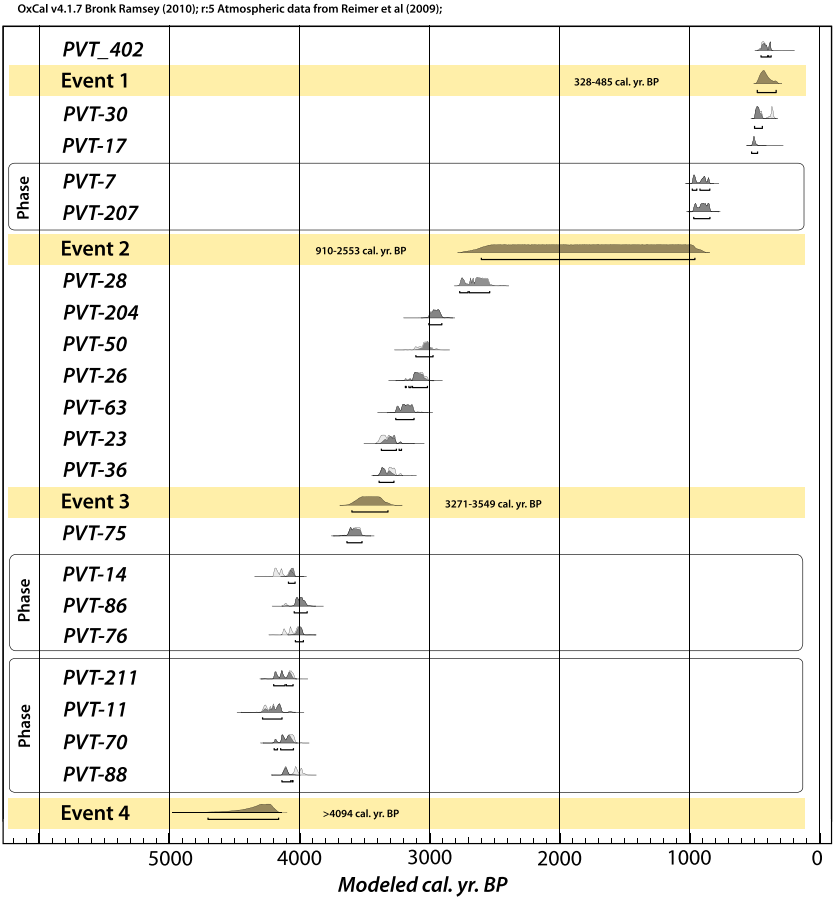

Figure 7. Chronological ordering model created in OxCal v4.1 [Ramsey, 2001] with probability density functions for individual radiocarbon samples. Calibrated unmodeled radiocarbon distributions (prior probability distributions) are shown with the light grey curves, and modeled distributions (posterior stratigraphically ordered distributions) are shown with the black curves. Modeled distributions of our four events are highlighted. Samples that are arranged in phases represent coherent units from which each of those samples was taken. Organizing them into phases indicates that the samples internal ordering is not known and the samples are dated as a package.

unmodeled]), was collected from Unit A on the south wall of $\mathrm{T}-2$ at a depth only $15 \mathrm{~cm}$ below the playa surface. Although these ages indicate an average sediment accumulation rate over the past $4.3 \mathrm{ka}$ of approximately $0.85-0.9 \mathrm{~mm} / \mathrm{yr}$, the rate probably varied during this period as shown in Figure 5. Between circa 950 and $2450 \mathrm{cal}$. yr. BP the sediment accumulation rate is unknown because we did not date any charcoal samples recovered from within the Paleosol out of concern for possible reworking within the generally massive unit. Interestingly, we observe a slight increase in the sediment accumulation rate after both Event 1 and Event 3. This seems logical with large earthquakes producing rockfalls, which can in turn lead to a greater sediment supply to the playa. We were unable to determine whether a similar sediment accumulation rate increase occurred after Event 2 because of inadequate age control within the Paleosol.

[15] The radiocarbon data show relatively continuous sediment accumulation over the past $\sim 4 \mathrm{ka}$, with the exception of a period of reduced sediment accumulation rate associated with the development of the prominent soil observed in the trench. Conversations with soil expert Eric McDonald in the field, based solely on his visual examination of the Paleosol exposed in the trench, suggested a duration of $\sim 1000$ years for development of the Paleosol (E. McDonald, personal communication, 2010). This field assessment of the degree of soil development supports our preferred interpretation of the radiocarbon data, which is that the soil developed between $\sim 950$ and 2550 cal. yr. BP.

[16] In addition to the charcoal samples, we collected four optically stimulated luminescence (OSL) samples from the layers above and below Events 1 and 3 near fault strands 1 and 2 exposed in T-2 (Figure 3 ). Samples were collected using steel pipes pounded into the layers of interest and shipped to the Utah State University Luminescence Laboratory for analysis. Samples for soil moisture content and inductively coupled plasma-mass spectrometry analysis of environmental dose rate were collected from around each sample tube and sample depth noted for cosmic contribution to the dose rate [Prescott and Hutton, 1994]. In the lab, the samples were processed using heavy liquid $\left(2.7 \mathrm{~g} / \mathrm{m}^{3}\right.$ sodium polytungstate) and acid $(10 \% \mathrm{HCl}$ and three $30 \mathrm{~min} 47 \% \mathrm{HF})$ treatments to isolate the $63-125 \mu \mathrm{m}$ quartz and sand component (PVTOSL-4 sieved to $63-212 \mu \mathrm{m})$. OSL samples were analyzed using the single-aliquot regenerative-dose method [Murray and Wintle, 2000, 2003; Wintle and Murray, 2006] and early background subtraction method [Cunningham and Wallinga, 2010]. OSL ages of the older samples (PVT-OSL-1 and PVT-OSL-2) were calculated using the weighted mean of at least 18 accepted aliquots. Ages of the younger samples (PVT-OSL-3 and PVT-OSL-4) were calculated using a minimum age model [Galbraith et al., 1999] due to signs of incomplete bleaching of the luminescence signal at deposition (significant skew and high over dispersion).

[17] The resultant OSL ages are consistent with the radiocarbon chronology (Figures 3 and 4), suggesting that this methodology has accounted for partial bleaching and that OSL ages are reliable. Specifically, all four samples are within $2 \sigma$ error of the independent radiocarbon age measurements from the same stratigraphic units, though the event ages still remain better constrained using the radiocarbon ages. Nevertheless, the success of the OSL dates and their consistency with the ${ }^{14} \mathrm{C}$ ages at the Playa Verde Trench provides confidence in using OSL dating methods in playa sediments. Information regarding the dose rates for each sample can be found in the data repository.

\section{Interpretation of Paleo-surface Ruptures}

[18] Trench T-2 revealed five main fault strands, referred to as faults 1 through 5 (Figure 3), from east to west, with most slip occurring on strand 3 near the middle of the trench. A prominent $2 \mathrm{~m}$ deep, upward widening fissure marks the trace of fault 3. The multiple-stranded nature of the fault zone in T-2 was also observed in $\mathrm{T}-1$ and is similar to the geomorphic expression of the fault zone to the north of our trench site. Multiple lines of mutually consistent evidence along these five fault strands allowed us to identify three well-defined earthquake horizons and a poorly constrained fourth faulting event. We refer to the most recent earthquake (MRE) as Event 1 and the oldest as Event 4. In addition to fissure fills, the geometry of growth strata, and upward fault terminations, our identification of these events was facilitated by incremental structural reconstruction of the strata deformed by fault 3 (Figure 6).

[19] The ages of each event reported in Figure 7 are based on calculations using OxCal's stratigraphic ordering model. The overall agreement index (an OxCal-based measure of 

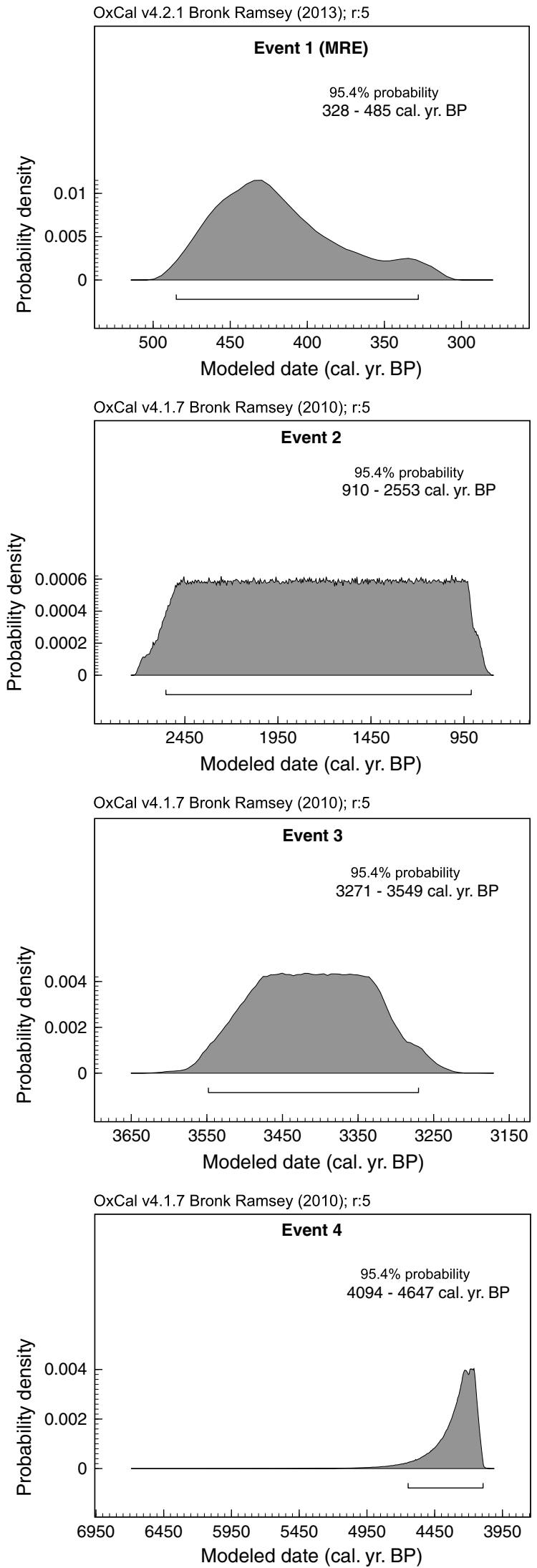

Figure 8. Modeled probability density function of the four paleoseismic events identified in T-2 using the web-based OxCal v4.1. The age range shown in each graph is the $2 \sigma$ confidence interval. the internal consistency of the probability distribution function relative to stratigraphic order) for our final model (Figure 7 and Table 1) is $99.6 \%$.

\subsection{Event 1}

[20] Event 1, the most recent event, is best expressed by a large ( $>1 \mathrm{~m}$ wide, $3 \mathrm{~m}$ deep) fissure that formed along fault 3. Multiple lines of evidence indicate an event horizon within $\sim 40 \mathrm{~cm}$ of the present-day ground surface. Although less pronounced, this feature was also observed along this same fault in $\mathrm{T}-1,45 \mathrm{~m}$ to the north, indicating that it is laterally extensive. Following the MRE, the fissure was filled with two sedimentary deposits: an initial deposit of fragmented, colluvial sand and silt blocks derived from strata exposed in the fissure walls up to a depth of $1.5 \mathrm{~m}$, and a later sequence of the playa silts and clays deposited above the colluvium, which exhibit growth stratal geometries and onlap onto the eroded remnants of the fissure walls. The fissure widens upward, reflecting gradual collapse and erosion of the originally near-vertical walls (including the upward extent of fault 3). Within the top $20 \mathrm{~cm}$ of the trench, the horizontally stratified playa deposits are continuous across the buried fissure. Well-bedded and flat-lying silt Units B and G are vertically separated by $\sim 20 \mathrm{~cm}$ across the fissure, indicating that approximately $20 \mathrm{~cm}$ of eastside-up vertical separation occurred during the MRE along fault 3 (Figure 6).

[21] On the north wall of the trench T-2 a small-displacement fault with $2-4 \mathrm{~cm}$ of vertical separation across several thin-bedded silty clay layers and a crack with no discernible offset are exposed near the base of the colluvial fissure fill at meters 11.5 and 11.0 , respectively. The presence of this minor fault within the lower part of the fissure fill suggests either (1) that minor fault slip has occurred since the MRE, possibly triggered by large aftershocks or by earthquakes on other, nearby faults; (2) that this small-displacement fault occurred during post-earthquake settling or as a result of shrink and swell processes (desiccation cracks) that may have played a role in the early stages of post-event deposition; or (3) that the lowermost part of the large fissure actually formed during the penultimate event and was subsequently reactivated and enlarged in the MRE. Insofar as this one small-displacement fault is the only structural evidence suggestive of pre-Event 1 faulting in the trench, we consider this third scenario unlikely (see additional discussion in supplementary data).

[22] Additional evidence for the MRE includes offset strata at fault 1 in T-2 (meter 3-north wall, meter 5.4- south wall), where a particularly well-defined down-dropped block of well-bedded playa sediments (Units $G$ and B) is overlain by laterally extensive, unbroken playa clays and silts (Unit A) at $25 \mathrm{~cm}$ depth (Figure 4). Specifically, there are four to five thin silty clay beds within the upper $40 \mathrm{~cm}$ of the trench that can be traced for most of the length of the trench (green beds in Unit A of Figure 3). The lowermost of these silty clays was not faulted during the MRE. Thus, the event horizon lies within the lowermost part of Unit A, below the lowest silty clay interbed. Another possible indication of a young event within the top few tens of centimeters comes from fault strand 4, which exhibits a vertical separation of $1-2 \mathrm{~cm}$ and terminates upward at a similar position in Unit A. Based on the amount of structural separation evident along these three fault strands, most slip in the MRE appears to have occurred on fault strand 3. 


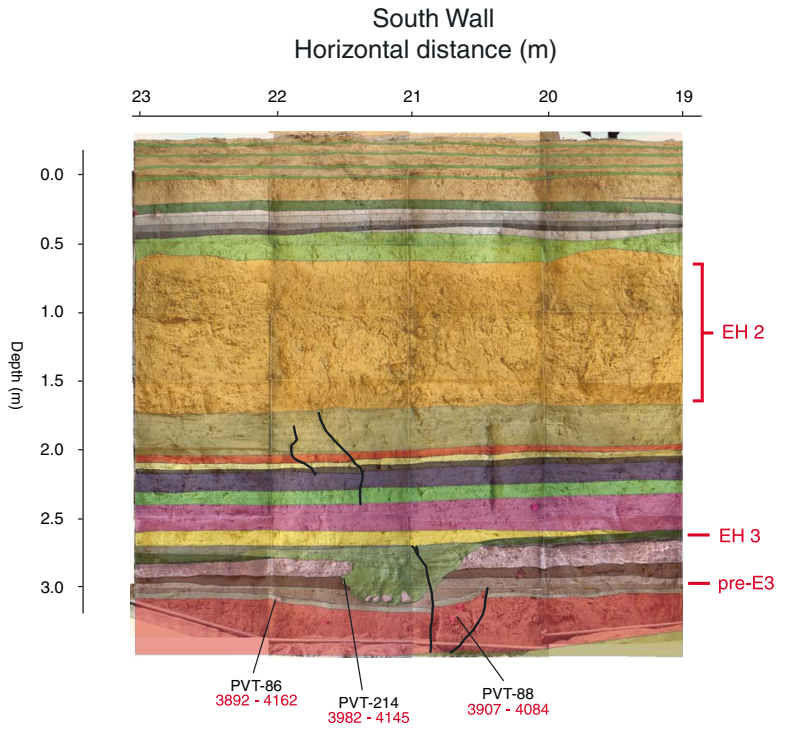

Figure 9. Fault strand 5 on south wall. Digital log is draped over photomosaic between meters 19 and 23. Fault 5 at this location shows evidence for Event 3 and a possible pre-Event 3.

[23] The timing of the MRE was determined using samples PVT-402 from Unit A, a package of silty clay layers that forms the current playa surface, and samples PVT-30 and PVT-17. PVT-30 was collected from the faulted base of Unit A at fault strand 4, and PVT-17 was collected from the top of Unit $\mathrm{G}$, a $7 \mathrm{~cm}$ thick, light olive brown silt layer that is the shallowest definable layer displaced by fault strand 1. As explained above, we are unable to use the samples within the fissure to constrain the MRE because they are part of the unidentifiable colluvial deposits filling the base of the fissure and were likely derived largely from erosion and collapse of the fissure walls following its opening during the MRE. Similarly, we do not use the samples from the growth stratigraphy at the base of the fissure because they are 200-400 years older than PVT-17 from just below the MRE horizon. This indicates that the samples within the growth strata at the base of the fissure must have been eroded off the side of the fissure walls from deposits that were between 200 and 400 years older than the playa surface at time of Event 1. PVT-302 yields an age range that is similar to the ages of samples above the event horizon collected from other locations within the trench, suggesting that it may record partial infilling of the fissure by typical playa sediment accumulation; however, we did not include this sample in our final OxCal model because its exact stratigraphic position relative to the event horizon is not clear.

[24] Using samples PVT-402, PVT-30, and PVT-17 as our constraining dates, we obtain a calibrated calendric age for the MRE of 315-483 cal. yr. BP. This range provides a maximum age range for this event. Our OxCal 4.1 stratigraphic ordering model yields a preferred range for the MRE of $328-485$ cal. yr. BP $(95.4 \%$ confidence interval) with a peak probability at $\sim 425$ cal. yr. BP (Figures 7 and 8). Sample PVT-52 was found within the well-bedded sands and silts that comprise the fill material in the top half of the large fissure at fault strand 3. We did not include this sample in our final model because of the possibility that the sample was eroded off the wall of the fissure. However, when this sample is included into the stratigraphic ordering model (and assumed to be deposited after the MRE), we obtain an age of $364-498 \mathrm{cal}$. yr. BP for our MRE. The PDF for this alternative reconstruction is found in the data repository.

\subsection{Event 2}

[25] Multiple lines of mutually supportive evidence indicate that the event horizon for Event 2, the penultimate event, lies within the Paleosol. The strongest evidence comes from incremental reconstructions of the strata around the large fissure in the middle part of the trench that formed during the MRE. As shown in Figure 6, the MRE resulted in a total of $\sim 20 \mathrm{~cm}$ eastside up vertical separation for Units $G$ and $B$ (directly on top of the Paleosol). Units L to F (directly below the Paleosol) show $\sim 70 \mathrm{~cm}$ of total eastside up vertical separation. The reconstructions show that no vertical separation was produced along fault 3 at the Event 3 horizon (Unit P), indicating that $\sim 50 \mathrm{~cm}$ of eastside-up vertical separation along fault strand 3 had to have occurred during one or more events between deposition of Units L-F and B-G, with the MRE providing an additional $\sim 20 \mathrm{~cm}$ of eastside-up vertical separation, after the deposition of Units G, B, and the lower part of Unit A.

[26] Other evidence for Event 2 comes from fault 5 and another minor fault strand observed on the south wall of T-2 at meter 3. At both of these locations, the fault strand extends upward and terminates within the Paleosol. On both the north and south walls of the trench, fault 5 displaces the base of the prominent Paleosol by $\sim 3 \mathrm{~cm}$, but beds above the meterthick Paleosol are clearly not displaced. This indicates that either the penultimate event occurred during development of the soil or that fault 5 represents a strand that slipped in the MRE but which did not reach the surface. On the south wall of T-2, an additional fault strand at meter 3.5 extends up through the Paleosol with several centimeters of displacement shown on several thin-bedded, laterally discontinuous coarse sand units just below the Paleosol. These sand layers cannot be identified on the north wall. The silt beds above the Paleosol near meter 3.5 show no signs of faulting, indicating that the event horizon is within the Paleosol. The fault at meter 3.5 can be traced up to near the top of the Paleosol, and this suggests that the penultimate event may have occurred after the sedimentary layers within which the paleosol was developed had accumulated, perhaps as part of a temporal "couplet" of closely timed earthquakes together with the MRE.

[27] Because Event 2 occurred sometime during the deposition of the strata within which the Paleosol later formed, we cannot precisely constrain the age of this earthquake. The only reliable ages that we can use come from the samples directly below (PVT-28) and above (OxCal phase cluster of PVT-207 and PVT-7; Figure 3) the units that have been overprinted by the Paleosol. The phase cluster option in OxCal 4.1 allows us to group samples that are all from one coherent group but for which there is insufficient or no information on their internal ordering. This becomes important when we have samples from the same unit at different ends of the trench and where the exact stratigraphic relationship between the two samples cannot be determined, as is the case with samples PVT-207 and PVT-7. Our preferred interpretation of the radiocarbon data suggests that at least one surface rupture occurred between 910 and 2553 cal. yr. BP, during 
deposition of the units that were overprinted by the paleosol (Figures 6, 7, and 8). Although it is possible that more than one surface rupture occurred during deposition of these units and subsequent period of soil development, our preferred interpretation is of a single surface-rupturing event. We have no structural observations to suggest the occurrence of more than one surface rupture in this interval.

\subsection{Event 3}

[28] Event 3 is best recorded on faults 2 and 5, with very little vertical separation evident on fault strand 3 (Figures 3 and 6). On fault strand 2, Unit $\mathrm{O}$, a white silt bed, and Unit $\mathrm{X}$, an alluvial gravel and sand deposit, exhibit $\sim 15 \mathrm{~cm}$ of westside-down vertical separation across a 60 to $80 \mathrm{~cm}$ wide fissure filled with colluvium and thinly and locally cross-bedded sands. In both the north and south walls at fault 2, Unit E lies unconformably across the fault trace and fissure fill. Small-scale cracking and faulting of Unit E indicates minor reactivation during a later event or events. The presence of well-bedded strata overlaying down-dropped blocks of Unit $\mathrm{O}$ through $\mathrm{L}$ at fault strand 2 suggests that the event horizon at this fault can be placed above the top of Unit O, prior to the deposition of the bedded strata, and below Unit E (Figure 4). Fault strand 5 exhibits similar relationships indicating a stratigraphic position of the Event 3 horizon above Unit $\mathrm{O}$ and below Unit E. Specifically, in the north wall, Unit O is clearly vertically separated more than the base of Unit E (which was subsequently faulted during Event 2 as described above). Unit $\mathrm{P}$ is the growth stratum that fills in the accommodation space that resulted from down-dropping Unit E, onlapping older strata above a gentle west facing scarp. Unit $\mathrm{P}$, which is only observed along the west side of the trench, provides more precise stratigraphic resolution for the Event 3 horizon because it lies between Unit $\mathrm{E}$ and Unit $\mathrm{O}$. We attribute faulting of Unit $P$ on the north wall at fault 5 to be displacement during younger Event 2, as described above. At fault 5 on the south wall there is $12 \mathrm{~cm}$ of westside-down vertical separation of Unit X. This fault strand terminates upward at the base of Unit $\mathrm{P}$, which onlaps older strata and pinches out $1 \mathrm{~m}$ east of fault 5 . The unbroken nature of Unit $\mathrm{P}$ indicates that the event horizon is at the base of Unit P. Additional evidence for Event 3 includes a small fault strand at meter 13 of the north wall that vertically separates Units Y, $\mathrm{L}, \mathrm{R}, \mathrm{S}, \mathrm{U}$, and $\mathrm{X}$ by several centimeters but which terminates upward at the base of Unit E.

[29] The observations described above indicate a well-defined Event 3 horizon at the base of Unit P. However, detailed stratigraphic and structural observations at fault 5 on the south wall suggest the possibility that "Event 3" may actually record two closely spaced earthquakes. As described above, in three of the four exposures of the Event 3 horizon, at faults 2 and 5, there are well-bedded deposits overlying the down-faulted blocks of Units $\mathrm{O}$ through L. These do not appear to be faulted, suggesting that the event preceded deposition of the wellbedded strata. At fault 5 on the south wall, however, these well-bedded deposits are clearly displaced by a fault strand that exhibits a small fissure extending up to the base of Unit $P$ that is filled with Unit P silts (Figure 9). This observation appears to indicate that there are actually two closely spaced event horizons - one that created fissures along faults 2 and 5 and a slightly younger event horizon in which the fissure-fill deposits were offset along fault 5, prior to deposition of unit $\mathrm{P}$.
We note, however, that the fault 5 strand that cuts the wellbedded deposits and which exhibits the Unit P fissure fill can be observed on both walls to extend upward into the Paleosol, albeit discontinuously on the south wall. This strand therefore clearly ruptured during Event 2, and it is possible that the fissure fill along this strand at the base of Unit P does not record deformation of the ground surface during a postEvent 3 surface rupture. In light of the dearth of supporting evidence for two surface-rupturing events between units $\mathrm{O}$ and $\mathrm{P}$ and the possible alternative explanation for the fissure fill at the base of Unit P, we suspect that this is not a separate event horizon but rather a strand of the fault that ruptured during Event 2. In light of the highly cohesive nature of the playa silts exposed in our trench we suspect that there may have been open fissures below the ground surface that may have been filled by downward infiltration of Unit P material following Event 2.

[30] The timing of Event 3 is constrained by the 31693337 cal. yr. BP ${ }^{14} \mathrm{C}$ age from sample PVT-36, collected from Unit $\mathrm{E}$ about $1 \mathrm{~m}$ west of fault 2 in the north wall, and the 3470-3582 cal. yr. BP age from sample PVT-75 collected from Unit $\mathrm{O}$ about $1 \mathrm{~m}$ west of fault 4 in the south wall. Using only samples PVT-36 and PVT-75 as inputs to an OxCal model yields a maximum possible age range for Event 3 of 3246-3546 cal. yr. BP. Placing the ages of these samples together with the other samples in our OxCal model yielded a slightly more constrained age range for Event 3 of $3271-3549$ cal. yr. BP (95.4\% confidence interval), with the peak of the OxCal probability distribution function at between circa 3320 and 3480 cal. yr. BP (Figures 7 and 8). In addition to the possibility of a second event spaced closely in time with Event 3, two structures observed along the south wall of T-1 suggest the possibility that Event 3 was preceded by an additional slightly older event with an event horizon located $\sim 25 \mathrm{~cm}$ deeper than the well-defined Event 3 horizon at fault strand 5 . At meter 20.5 on the south wall, a small fault vertically separates Unit $\mathrm{R}$ by $\sim 3 \mathrm{~cm}$ (eastside down) and terminates within the lower half of Unit $\mathrm{S}$ (Figure 9). At meter 14, a small isolated fault strand splays off of the main fault of strand 4 and terminates at the same position within Unit $\mathrm{S}$. Unit $\mathrm{R}$ is also vertically separated a few centimeters (westside down) at this location. Though we cannot discount the possibility that these fault terminations provide evidence for an additional pre-Event 3 surface rupture, we suggest the alternative possibility that these small-displacement faults may record slip during Event 3, with displacement on these strands not reaching the surface [e.g. Bonilla and Lienkaemper, 1990]. If, however, these two upward fault terminations do record a pre-Event 3 surface rupture, the age of that earthquake would be constrained by sample PVT-75 and a phase cluster including samples PVT-86, PVT-14, and PVT-76. Constraining the event with these samples yields a maximum possible age range of $3524-3960$ cal. yr. BP (95.4\% confidence interval). The PDF for this potential preEvent 3 rupture can be found in the data repository.

\subsection{Event 4}

[31] Our fault strand 3 reconstruction revealed evidence for a fourth event (Figure 6). When reconstructing the stratigraphic units for Event 2, Unit Y (the deepest unit throughout most of the trench and likely part of the alluvial fan to the northwest) shows $\sim 30 \mathrm{~cm}$ of eastside up vertical separation. Because all of the events above Unit $\mathrm{Y}$ lie flat when 
reconstructed for pre-Event 3, this suggests that the vertical separation of Unit $\mathrm{Y}$ records a west facing fault scarp that formed before Event 3. Samples PVT-70 and PVT-88, the deepest dated charcoal samples, provide a minimum-possible age for Event 4 of $\sim 4000$ cal. yr. BP. Placing these samples in our OxCal stratigraphic ordering model, we obtain a minimum age of $4094 \mathrm{cal}$. yr. BP for Event 4 (Figures 7 and 8). No samples from within Unit Y were recovered; thus, we are not able to constrain the maximum age for Event 4 . No other evidence for a fourth event was observed in the trenches.

\section{Discussion}

[32] The occurrence of multiple event indicators within our trench has allowed us to identify at least three well-defined surface-rupturing events as well as a poorly constrained fourth event in the last $4 \mathrm{ka}$ at our site along the southern Panamint Valley fault. The identification of multiple paleoearthquakes at the Playa Verde trench site adds to the growing paleoseismological dataset for the region, and comparison of these results with previous data from other faults reveals several interesting patterns of earthquake occurrence (Figures 10 and 11). The 328-485 cal. yr. BP age of the MRE on the Panamint Valley fault falls within the ongoing seismic cluster of earthquakes since $\sim 1.0-1.5 \mathrm{ka}$ in the Mojave region to the south of the Garlock fault [Rockwell et al., 2000; Rymer et al., 2002; Ganev et al., 2010]. Other recent earthquakes that have occurred during the current Mojave ECSZ cluster include the MRE on the Owens Valley fault (the historical 1872 rupture), and a young $(<300 \mathrm{yr})$ surface rupture on the Death Valley fault system revealed by geomorphically youthful fault scarps and offset Ubehebe Crater tephra [Slate, 1999; Klinger, 2002]. In addition, the well-constrained $3.27-3.55 \mathrm{ka}$ age of our Event 3 overlaps with the $3.3-3.8 \mathrm{ka}$ age of the penultimate surface rupture on the Central Owens Valley fault [Lee et al., 2001a]. While the MREs on the Panamint Valley and Owens Valley faults illustrate a possible coupling between the two faults, the occurrence of Event 2 at our trench site demonstrates that the Panamint Valley fault also sometimes ruptures independently of the Owens Valley fault (Figure 11).

[33] The ongoing seismic cluster in the Mojave section of the ECSZ over the past $\sim 1000-1500$ years was preceded by a long seismic lull from 2 to $5 \mathrm{ka}$ [Rockwell et al., 2000]. Thus, although the MREs on the Panamint Valley fault, Owens Valley fault, and probably the Death Valley fault occurred during the ongoing Mojave cluster, the $\sim 3.5 \mathrm{ka}$ age of Event 3 on the Panamint Valley fault (as well as the $3.3-3.8$ ka penultimate earthquake on the Owens Valley fault) occurred in the middle of the $2-5 \mathrm{ka}$ Mojave lull. Together, these data suggest complex fault behavior in which ECSZ faults north of the Garlock fault sometimes rupture in clusters together with the faults in the Mojave region. The timing of these events along the Panamint Valley fault, together with the events in the Mojave region of the ECSZ, suggests a mechanism that operates at the scale of the entire plate boundary with stress and strain capable of being transferred across the Garlock fault. How such strain is transferred across a truncating $>200 \mathrm{~km}$ long fault system that is clearly not cut by any other fault is still very much debated.

[34] An even more complex spatiotemporal pattern of earthquakes is revealed when we consider the ages of Garlock fault earthquakes. Specifically, the $328-485$ cal. yr. BP age of the MRE on the Panamint Valley fault is very similar to the well-constrained 1450-1640 A.D. age of the MRE on the central Garlock fault [Dawson et al., 2003]; Madugo et al. [2012] document a similar MRE age on the western Garlock fault. Moreover, the age range of Panamint Valley fault Event 2 overlaps with the 1000-1925 cal. yr. BP ages of a cluster of three surface ruptures observed by Dawson et al. [2003] at the Garlock fault trench site. In contrast, the $3.27-3.55 \mathrm{ka}$ age of Panamint Valley fault Event 3 occurred within a long lull (2-5 ka) in earthquake activity on the central Garlock fault [Dawson et al., 2003], indicating that the Panamint Valley fault does not always rupture within a short time of the Garlock fault. The recurrence of earthquakes along the central Garlock fault revealed by these paleoseismologic data shows periods of seismic clustering at $0.5-2 \mathrm{ka}$ and at 5-7 ka. This pattern, however, does not fit perfectly with either the pattern of earthquake recurrence observed within the Mojave region of the ECSZ or the ECSZ north of the Garlock fault.

[35] The importance of understanding patterns of earthquake occurrence on these fault systems increases significantly if we introduce the possible triggering effects from static stress changes following a PVF earthquake. By applying Coulomb function failure $(\triangle \mathrm{CFF})$ modeling to our study area, we can use our paleoseismological data to determine the likelihood of triggered events and assess the implications that an event on the Panamint Valley fault would have for the rest of southern California.

\subsection{Coulomb Failure Function Modeling}

[36] Coulomb failure function change $(\triangle \mathrm{CFF})$ models can be used to model changes in static stress on a target fault with a particular orientation caused by an earthquake on another fault or a different section of the same fault [e.g., King et al., 1994; Harris and Simpson, 1996; Stein et al., 1997]. Increases in Coulomb failure stresses on a fault are thought to advance the earthquake cycle of the target fault and bring it closer to failure. Whereas the triggering of an earthquake due to static stress changes has been observed over short time scales [e.g., King et al., 1994; King and Cocco, 2001; Doser and Robinson, 2002; Kilb et al., 2002], what is less well understood is whether earthquake clusters on longer time scales could be caused by Coulomb Failure Function stress changes, which are commonly much smaller (less than a few bars) than typical stress drops in earthquakes [10-100 bars; Kanamori and Anderson, 1975; Hanks, 1977; Kanamori and Allen, 1986; Kanamori, 1994]. Because the magnitudes of the Coulomb stress transfer presumed to cause the triggering of an adjacent fault are commonly orders of magnitude smaller than that of the earthquake stress drop, it would require that the second fault be close to failure, in order for that rupture to have had any effect from the static stress changes [e.g., Sammis and Dolan, 2003; Sammis et al., 2003; Dolan et al., 2003; Scholz, 2010]. As first noted by Sammis and Dolan [2003] and Sammis et al. [2003] and subsequently by Scholz [2010], regional clusters of earthquakes may be related to rather subtle changes in failure stresses acting on the faults. These researchers noted that the small $\Delta \mathrm{CFF}$ changes typical of regional earthquake interactions have a greater impact on the probability of future earthquake occurrence if the $\triangle \mathrm{CFF}$ is imposed on a target fault that is late in its strain 


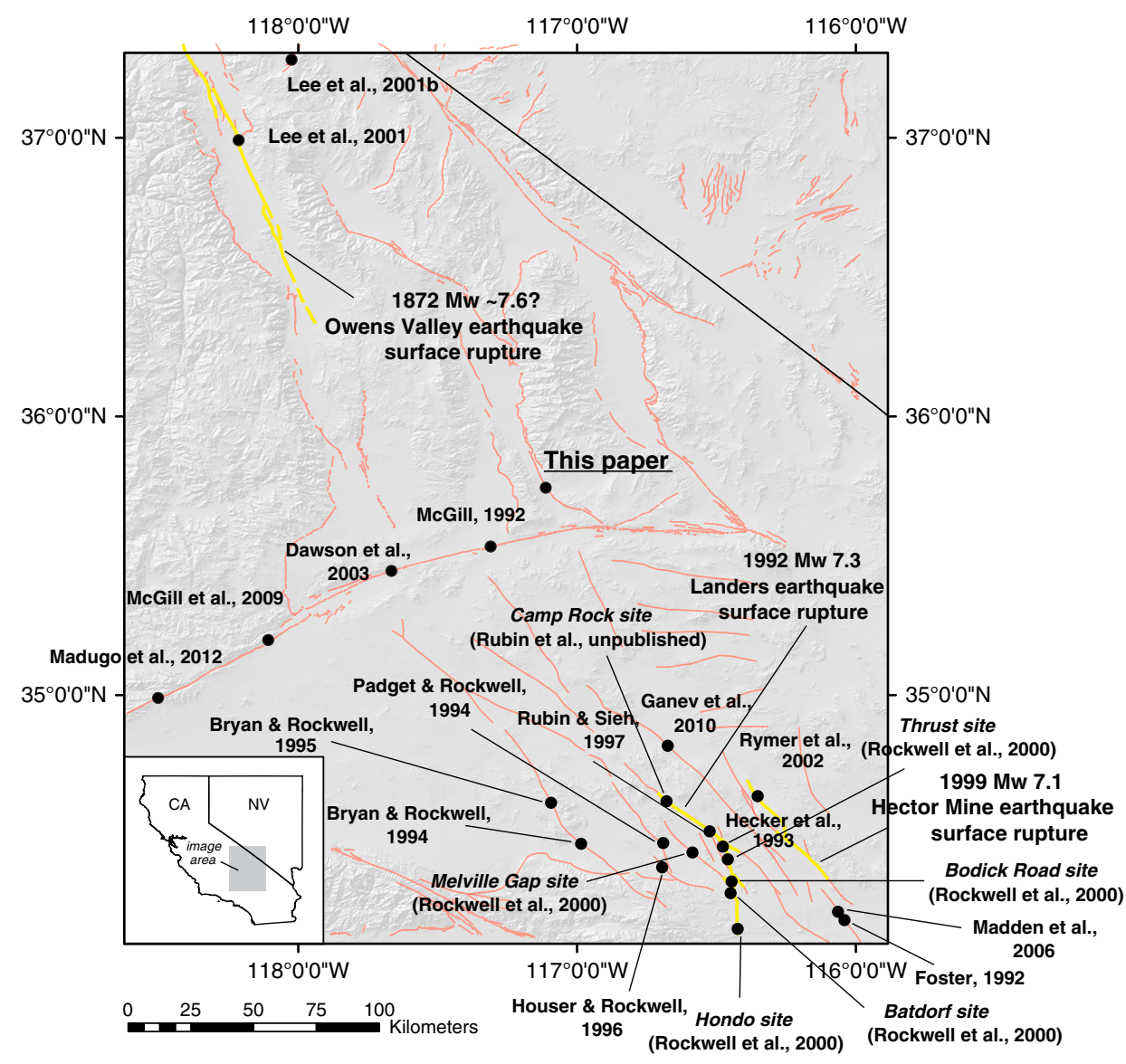

Figure 10. Map showing all of the paleoseismologic sites in the ECSZ and Garlock fault region. Red lines indicate Quaternary faults. Bold yellow lines indicate surface ruptures of the largest earthquakes within the historical record.

accumulation cycle. Sammis and Dolan [2003] and Sammis et al. [2003] took this one step further by demonstrating that if these $\triangle \mathrm{CFF}$ changes are consistently positive over the course of many earthquake cycles, the various interacting faults will lock into phase with one another. Using a simple oscillator model, Sammis and Dolan [2003] and Sammis et al. [2003] demonstrated that even if the faults start $180^{\circ}$ out of phase, they will gradually lock into phase as long as the stress interactions are consistently positive from earthquake cycle to earthquake cycle. Conversely, they showed that if stress interactions amongst faults are consistently negative, then even if the faults start in phase, earthquake occurrence will gradually lock $180^{\circ}$ out of phase over the course of many earthquake cycles. These models offer a likely explanation for the temporal and spatial clustering observed in the ECSZ, both north and south of the Garlock fault.

[37] Alternative explanations that may be mechanically complementary to the "phase lock" and "antiphase lock" models of Sammis and Dolan [2003] and Sammis et al. [2003] include (1) a kinematic model whereby two plate-boundary accommodating fault systems (San Andreas fault system and eastern California shear zone) alternate activity and in doing so suppress activity on the other fault system [Dolan et al., 2007]; and (2) a feedback mechanism whereby coseismic slip can introduce fluids into the ductile roots of fault zones, thereby increasing creep rates and therefore loading rates [Oskin et al., 2008]. While it is difficult to determine the exact mechanism responsible for the observed temporal cluster, it is worth noting that all of these processes may be mechanically complementary, and all could potentially be occurring to control earthquake clustering.

[38] The similarity in ages between the MREs on the Garlock and Panamint Valley faults is intriguing and, given the long recurrence interval for PVF events, suggests a possible causative relationship. To investigate this specific relationship, and more generally the implications of PVF earthquakes on regional seismic hazard, we conducted $\triangle \mathrm{CFF}$ modeling of various combinations of Panamint Valley fault and Garlock fault earthquakes. The results, shown in Figures 12 and 13, reveal several interesting patterns. For example, our models show that a rupture on just the southern Panamint Valley fault increases the Coulomb stresses along the central section of the Garlock fault but produces a slight stress shadow along the eastern part of the fault (Figures 12a and 12b). Rupture of the entire Panamint Valley fault produces the same effects but with a larger magnitude (Figures 12c and 12d). These results suggest that if the MRE on the Garlock fault occurred after and was triggered by rupture of the southern PVF, then the eastern Garlock fault may not have participated in the MRE on the Garlock fault. This is consistent with the results of the only paleoseismologic study of the Eastern Garlock fault, which 


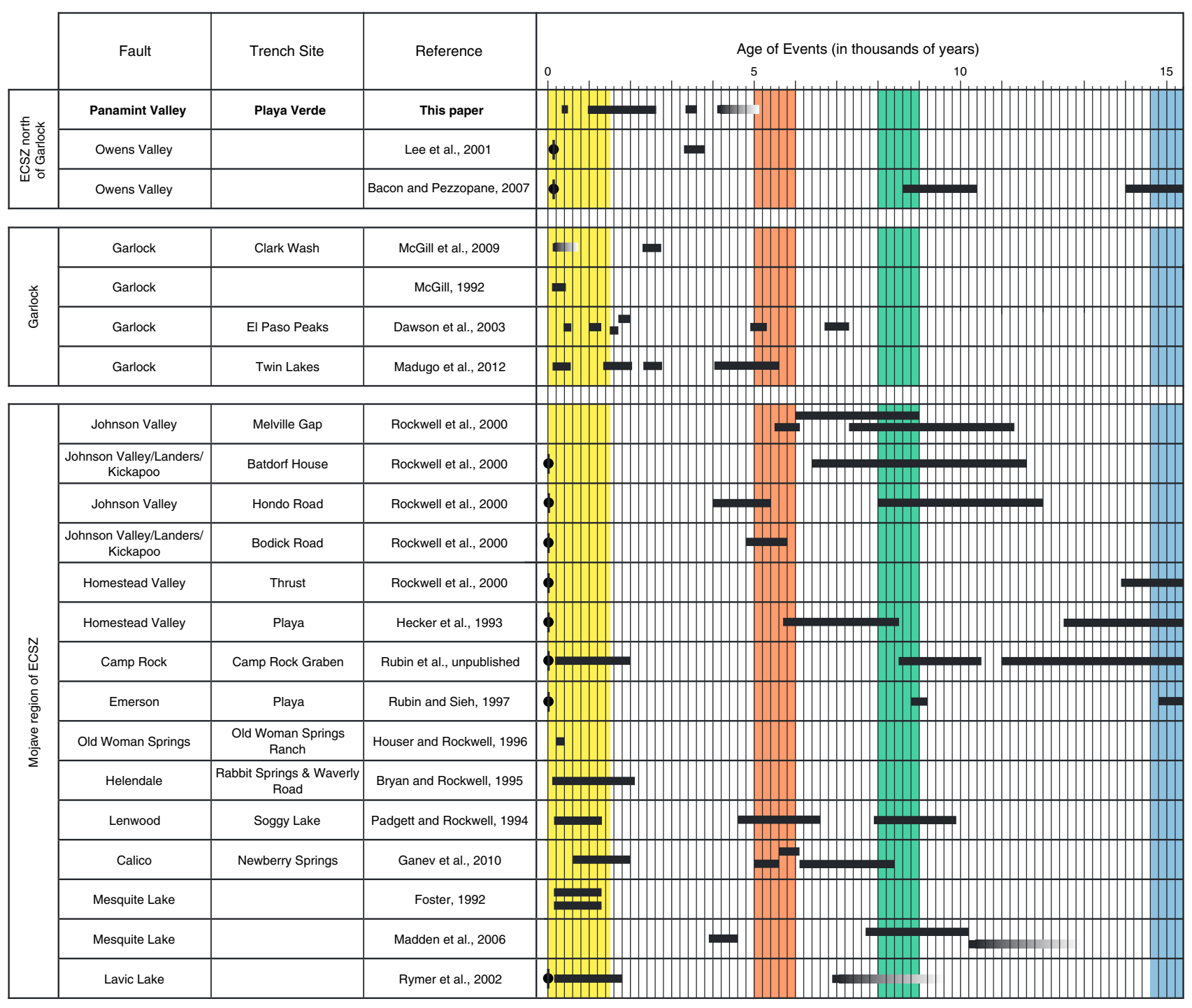

Figure 11. Chart showing the timing of past earthquakes at all trench sites in the ECSZ and on the Garlock fault. Bars with fading ends indicate no maximum age constraints are available. Black circles with lines through indicate earthquakes with known dates due to historical record. Colored bars indicate earthquake clusters (yellow: 0-1.5 ka, red: 5-6 ka, green: 8-9 ka, blue: $\sim 15 \mathrm{ka}$ ) reported by Rockwell et al. [2000] and Ganev et al. [2010]. Note that some earthquakes depicted at different sites are probably common events. Chart including data from Rockwell et al. [2000].

indicates that the most recent event on the Leach Lake strand in the northern Avawatz Mountains occurred sometime after 150-590 A.D. [McGill, 1993], considerably earlier than the $\sim 1500$ A.D. MRE on the central Garlock fault [Dawson et al., 2003].

[39] We tested variations in the slip, rupture length, and shear modulus in our $\triangle \mathrm{CFF}$ models. The results shown in Figure 12 indicate that greater slip along the length of the Panamint Valley-Brown Mountain fault system places the Garlock fault in a state of greatest Coulomb static stress increase but places the eastern Garlock in a stress shadow. Conversely, rupture of the central Garlock fault increases the Coulomb stress at the southern end of the PVF and decreases the Coulomb stress farther north, with the length of fault for which Coulomb stress increases being dependent on the shear modulus used in the model (Figures 13a, 13b, and 13c). Rupture of both the western and central Garlock fault increases the Coulomb failure stresses along the southern Panamint Valley fault, whereas rupture of the eastern section of the Garlock fault and rupture of the entire Garlock fault places the southern Panamint Valley fault in a stress shadow (Figures 13d, 13e, and 13f). These $\Delta$ CFF patterns suggest that there have been and may continue to be interactions between the Garlock fault and the Panamint Valley fault. We were interested in whether the $\triangle \mathrm{CFF}$ modeling could discriminate between triggering of the Garlock fault MRE by a Panamint valley fault rupture or vice versa. It is clear from the model results, however, that longer ruptures of the Panamint Valley fault ( \pm Brown Mountain segment) encourages rupture of the central Garlock fault and that under certain conditions, rupture of the central ( \pm western) Garlock fault strongly encourages rupture of the Panamint Valley fault. If the model of Sammis and Dolan [2003] and Sammis et al. [2003] is correct, these mutually positive 

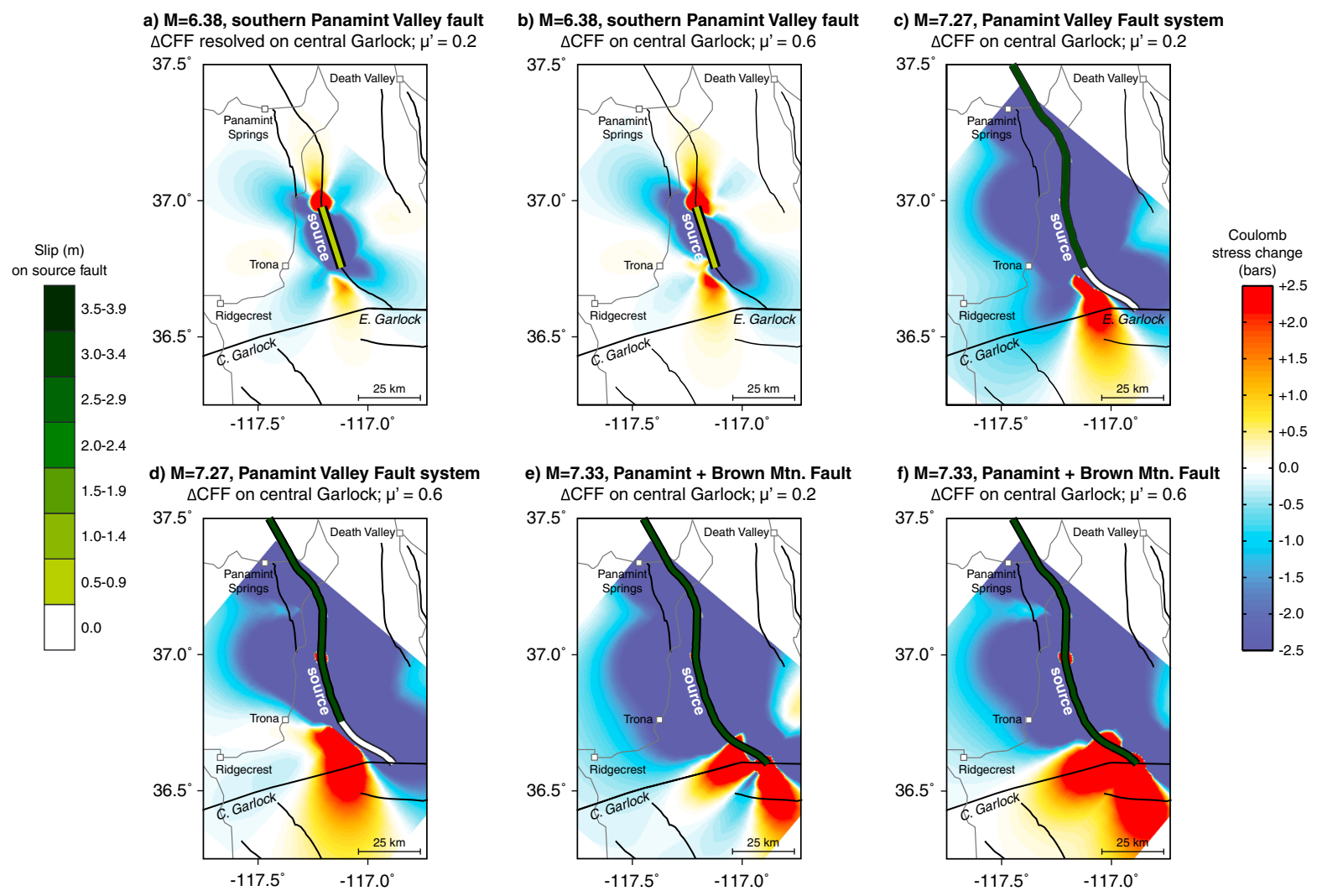

Figure 12. $\triangle \mathrm{CFF}$ imparted by simulated earthquakes on the Panamint Valley Fault (PVF) to the central Garlock Fault. In the panels, $\Delta \mathrm{CFF}$ is resolved on faults with strike $75^{\circ}$, dip $90^{\circ}$, and rake $0^{\circ}$, the inferred orientation and rake of the central Garlock Fault (CGF) in Pilot Knob Valley (PKV), its closest approach to the PVF (if the Brown Mountain Fault is not included as part of the PVF). In the values given below, $\triangle \mathrm{CFF}$ is resolved on the changing orientation of the Garlock along its length, with location-dependent strike, assumed dip $90^{\circ}$, and assumed rake $0^{\circ}$. Slip at each point on the PVF is uniform between 0 and $10 \mathrm{~km}$ depth and zero below that. Calculation depth is $5 \mathrm{~km}$ in all panels and for the values reported below. (a) Assuming $\mu^{\prime}=0.2$, a $M=6.38$ earthquake with $0.5 \mathrm{~m}$ of slip on the southern PVF induces $\Delta \mathrm{CFF}=-0.2$ bar on the CGF south of Searles Valley, $\Delta \mathrm{CFF}=+0.4$ bar on the CGF in Pilot Knob Valley, and $\triangle \mathrm{CFF}=-0.3$ bar on the eastern Garlock Fault (EGF). (b) Assuming $\mu^{\prime}=0.6$, the same event induces $\Delta \mathrm{CFF}=-0.1$ bar south of Searles Valley, $\Delta \mathrm{CFF}=+0.6$ bar in Pilot Knob Valley, and $\Delta \mathrm{CFF}=-0.5$ bar on the EGF. (c) Assuming $\mu^{\prime}=0.2$, a $M=7.27$ earthquake with $3 \mathrm{~m}$ of slip on the entire PVF from Hunter Mountain to the trench site induces $\Delta \mathrm{CFF}=-1.3$ bars on the CGF south of Searles Valley, $\Delta \mathrm{CFF}=+4.4$ bar on the CGF in Pilot Knob Valley, and $\Delta \mathrm{CFF}=-3.1 \mathrm{bar}$ on the eastern Garlock Fault (EGF). (d) Assuming $\mu^{\prime}=0.6$, the same event induces $\Delta \mathrm{CFF}=-0.3$ bar SW of Searles Valley, $\Delta \mathrm{CFF} \leq+6.1$ bar in Pilot Knob Valley, and $\Delta \mathrm{CFF} \geq-4.8$ bars on the EGF. The stress changes in Figures $12 \mathrm{e}$ and $12 \mathrm{f}$ are amplified if $3 \mathrm{~m}$ of right-lateral slip on the Brown Mountain Fault (BMF) is added to the events in Figures $12 \mathrm{c}$ and $12 \mathrm{~d}$. In addition, the decrease in $\triangle \mathrm{CFF}$ southwest of Searles Valley is also less powerful: $\Delta$ CFF there is -0.4 bar for $\mu^{\prime}=0.2$ and -0.1 bar for $\mu^{\prime}=0.6$ in this scenario.

$\triangle \mathrm{CFF}$ changes would suggest that ruptures of the Panamint Valley fault and central ( \pm western) Garlock fault would tend to be in phase with one another. This appears to fit existing data for Event 1 and perhaps Event 2 on the Panamint Valley fault but not Event 3, which seems to have occurred during a seismic lull on the Garlock fault.

\subsection{Implications for Seismic Hazard in Southern California}

[40] The Panamint Valley fault traverses a very sparsely populated region, with Ridgecrest (population 27,600) and Trona (population 2740 ) the only population centers of $>2000$ people within $100 \mathrm{~km}$ of the PVF (Figure 1a).
Thus, although the seismic hazard associated with this fault is significant, the local seismic risk from future PVF earthquakes is relatively low. Yet our $\triangle \mathrm{CFF}$ modeling suggests that an event on the PVF has the potential to trigger a large event on the central and western Garlock fault by increasing its Coulomb failure stress. Exploring this line of reasoning still further, $\triangle \mathrm{CFF}$ modeling by Rollins et al. [2010] and Rollins [2011] indicates that one possible scenario of concern would be a large central + western Garlock rupture that leads to an increase in $\triangle \mathrm{CFF}$ stresses on the Mojave section of the San Andreas fault, which extends closest to the Los Angeles metropolitan region. Thus, although the Panamint Valley fault traverses a remote and sparsely populated area, the 

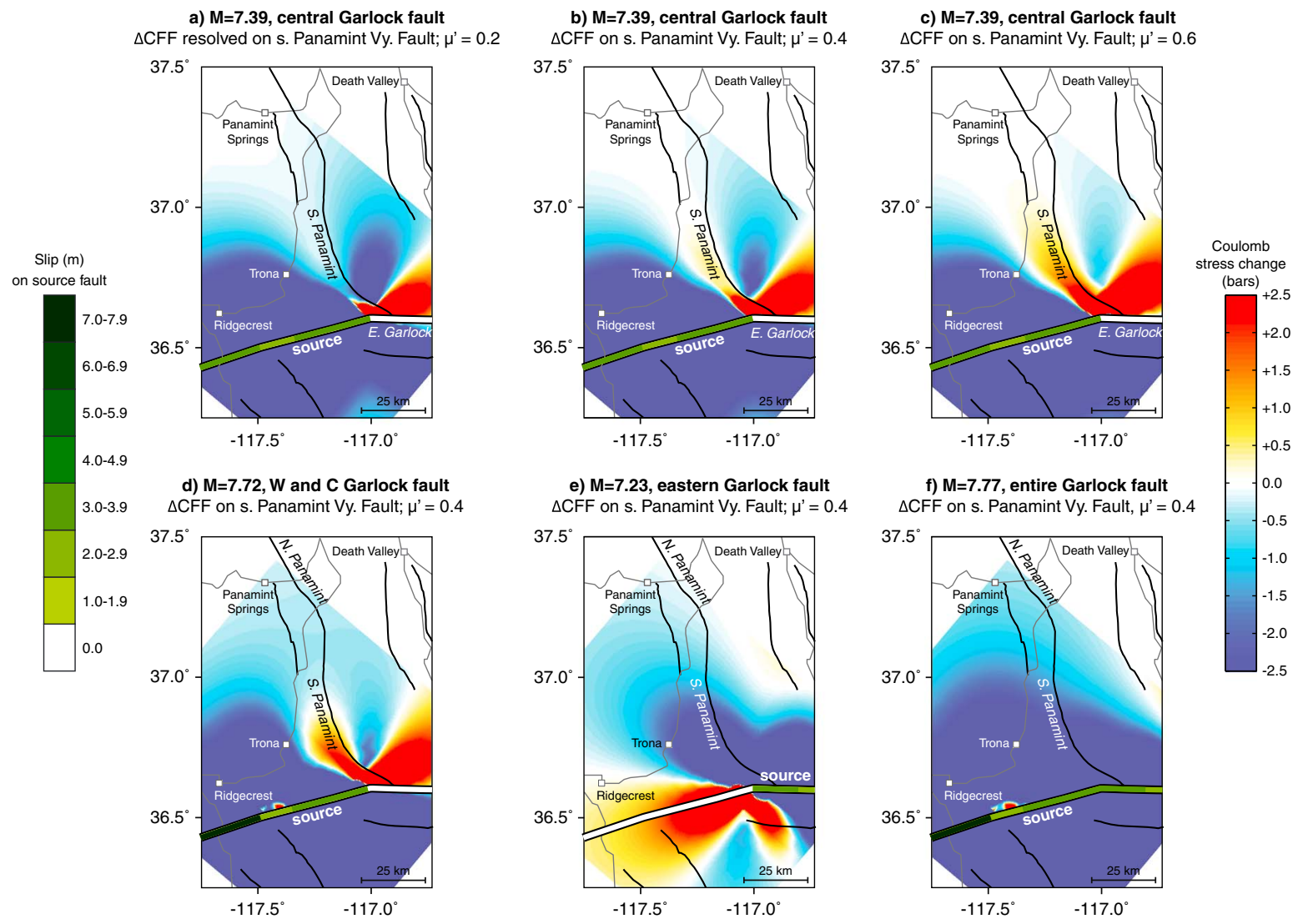

Figure 13. Coulomb static stress changes $(\triangle \mathrm{CFF})$ imparted by simulated earthquakes on the left-lateral Garlock Fault and resolved on faults with strike $162^{\circ}$, dip $90^{\circ}$, and rake $180^{\circ}$, the inferred orientation and rake of the Panamint Valley Fault (PVF) at the trench site. Slip at each point on the Garlock is uniform between 0 and $15 \mathrm{~km}$ depth and zero below $15 \mathrm{~km}$. Calculation depth is $5 \mathrm{~km}$ in all panels and in the numerical $\Delta$ CFF values reported below. (a) A $M=7.39$ earthquake on the CGF induces $\Delta \mathrm{CFF}=-0.7$ bar on the PVF at the trench site, assuming $\mu^{\prime}=0.2$. McGill and Sieh [1991] inferred $\sim 7 \mathrm{~m}$ of offset in the apparent MRE on the CGF south of El Paso Peaks, dated to 1450-1640 Common Era by Dawson et al. [2003]. Slip is $0 \mathrm{~m}$ on the western Garlock Fault (WGF) in this CGF-only source, and so we artificially set slip south of El Paso Peaks to $3 \mathrm{~m}$ to avoid an unrealistic slip discontinuity at Koehn Lake. Otherwise, slip values on the CGF are smoothed McGill and Sieh [1991] offsets. Slip is $0 \mathrm{~m}$ on the EGF. (b) Assuming $\mu^{\prime}=0.4$, the same CGF event induces $\Delta \mathrm{CFF}=+0.4$ bar at the trench site. (c) Assuming $\mu^{\prime}=0.6$, the same CGF event induces $\Delta \mathrm{CFF}=+1.5$ bars at the trench site. (d) Assuming $\mu^{\prime}=0.4$, a $M=7.72$ event on the WGF and CGF induces $\Delta \mathrm{CFF}=+1.5$ bars at the trench site. Slip values in this event are $4 \mathrm{~m}$ on the WGF, smoothed McGill and Sieh [1991] offsets on the CGF, and $0 \mathrm{~m}$ on the EGF. (e) Assuming $\mu^{\prime}=0.4$, a $M=7.23$ event on the EGF induces $\triangle \mathrm{CFF}=-6.7$ bars at the trench site. Slip values in this event are based on McGill and Sieh [1991] offsets on the EGF and set to $0 \mathrm{~m}$ on the WGF and CGF. (f) Assuming $\mu^{\prime}=0.4$, a $M=7.77$ event rupturing the entire Garlock Fault induces $\Delta \mathrm{CFF}=-5.2$ bars at the trench site. Slip values in this event are set to $4 \mathrm{~m}$ on the WGF and based on McGill and Sieh [1991] offsets on the CGF and EGF.

occurrence of earthquakes on this relatively remote fault could potentially act as a trigger for a cascade of failures that could eventually include a large-magnitude earthquake on the San Andreas fault (SAF). Indeed, the paleoseismological data indicate that at least sometimes these three faults all rupture within a brief period. The most recent event on the central Garlock fault, dated to between 1450 and 1640 A.D. [Dawson et al., 2003; McGill, 1992], produced a maximum of 7+m of surface slip [McGill and Sieh, 1991]. The third event back on the San Andreas fault at Pallett Creek is currently dated at a preferred ("fully constrained") age of A.D. 1508 (95\% range $=1457-1568$ A.D.) based on revised dates by Scharer et al. [2011]. The ages of these events, together with the age of the MRE on the Panamint Valley fault, suggest a potential link in the possible rupture pattern of all three faults over a relatively short time period in the fifteenth to seventeenth centuries. Our $\triangle \mathrm{CFF}$ models illustrate that a chain of events beginning along the southern Panamint Valley fault has the potential to trigger a rupture along the central Garlock fault (Figure 14). Rollins et al. [2010] and Rollins [2011] show that such a Garlock fault event would in turn increase the Coulomb failure stresses on the Mojave section of the San Andreas fault, enhancing the likelihood of potential triggering of a rupture along this section of the southern San Andreas fault (Figure 13). The sequential ages of the three events dramatically changes the short-term 

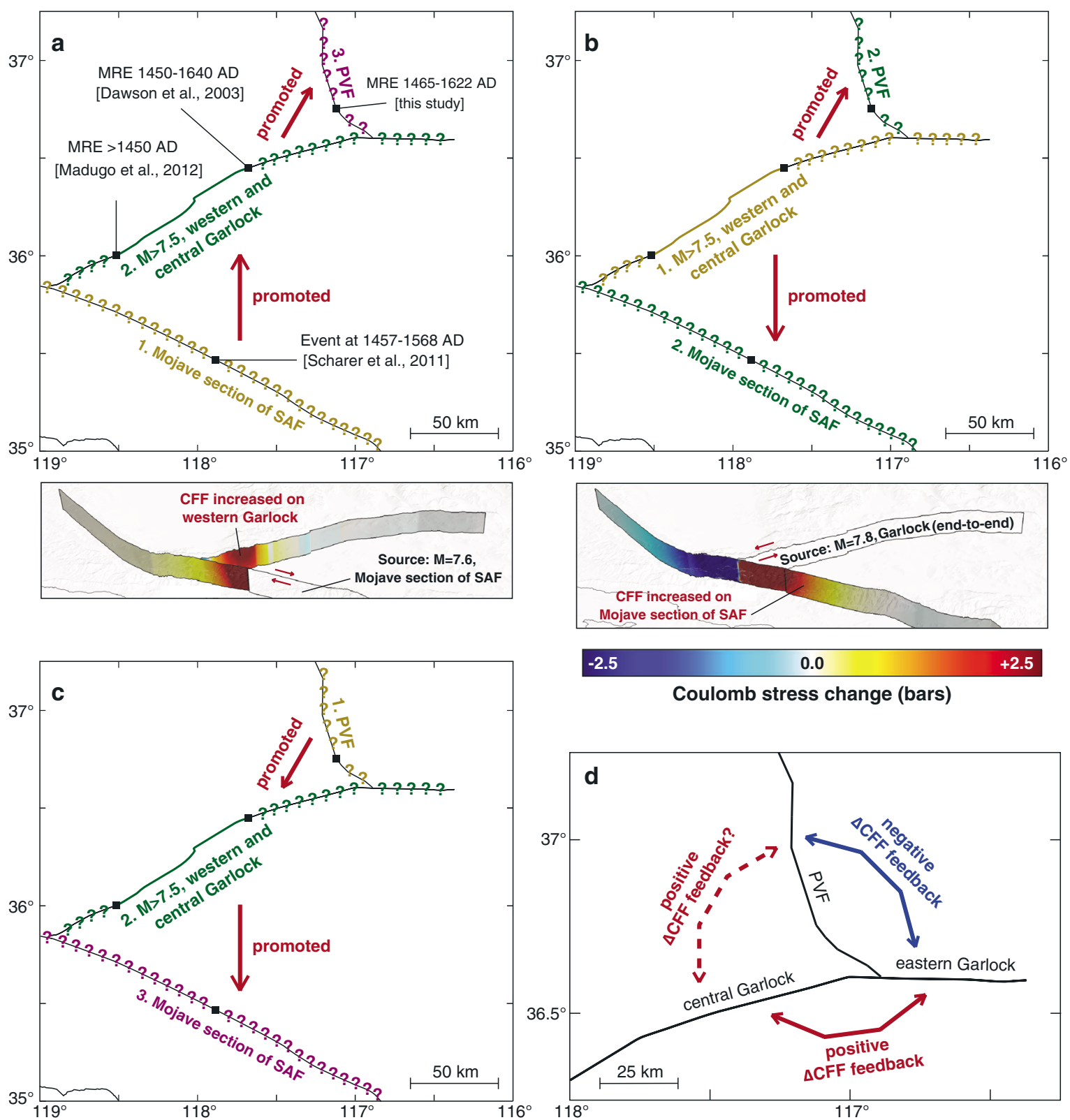

$-2.5$

Coulomb stress change (bars)

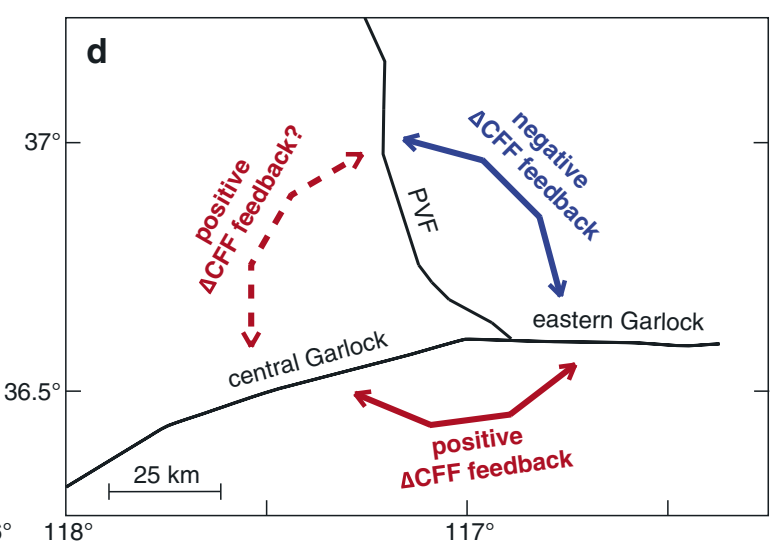

Figure 14. Possible interactions between excavated earthquakes circa 1500 A.D. on the Panamint Valley Fault, the Garlock Fault, and the Mojave section of the San Andreas. The black boxes are our trench site on the southern PVF, the El Paso Peaks site on the central Garlock [McGill and Sieh, 1991; Dawson et al., 2003], the Twin Lakes site on the western Garlock [Madugo et al., 2012], and Pallet Creek on the SAF. Due to the observation of 7+ $\mathrm{m}$ of slip in the 1450-1640 A.D. MRE at the El Paso Peaks site, we postulate that that event and the $>1450$ A.D. MRE on the western Garlock are the same event. (a) Second panel: A $M=7.6$ event rupturing the Mojave section of the SAF would likely increase CFF on the western Garlock (Rollins et al., unpublished). First panel: The 1455-1622 A.D. event on the Mojave section of the SAF promotes the MRE on the western and central Garlock, which in turn promotes the MRE on the PVF (Figure 13). (b) Second panel: A $M=7.8$ end-to-end event on the Garlock would likely increase CFF on the Mojave section of the SAF (Rollins et al., unpublished). An event rupturing only the western and central Garlock would have a similar effect because the eastern Garlock does not greatly affect the SAF. First panel: The postulated single MRE on the western and central Garlock increases CFF both on the Mojave section of the SAF and on the PVF. (c) The MRE on the PVF promotes the MRE on the Garlock (Figure 12), which in turn promotes the circa 1500 A.D. event on the Mojave section of the SAF. (d) Schematic of the likely stress interactions between the central Garlock, the eastern Garlock, and the PVF based on Figures 12 and 13. 
seismic hazard assessment for southern California. Although paleo-earthquake data cannot prove this sequence of events, the available paleoseismologic data are consistent with the failure of all three of these faults within a brief period of time during the fifteenth to sixteenth centuries [McGill 1992; Biasi et al., 2002; Dawson et al., 2003; Scharer et al., 2011; Madugo et al., 2012; this study].

\section{Conclusions}

[41] Three surface ruptures have occurred on the southern Panamint Valley fault at our trench site during the past 3600 years, with an additional event occurring at some time before $4.1 \mathrm{ka}$. The MRE and the third event back are well defined by multiple, mutually consistent lines of evidence exposed in the trench walls, and calibrated radiocarbon dates of 20 charcoal samples tightly constrain these surface ruptures to the fifteenth century to early sixteenth century $(328-485$ cal. yr. BP) and at 3.27-3.55 ka, respectively. The penultimate event occurred during a period of slow deposition and soil development spanning $0.91-2.55 \mathrm{ka}$. Future studies at this site should focus on excavation of a trench further south into the playa, where the fine-grained playa deposits are likely considerably thicker. Such a trench could potentially yield a longer record of earthquake occurrence on this part of the Panamint Valley Fault. In addition, excavation of an additional, more southerly trench could potentially help resolve the ambiguities involving the exact timing of Event 2.

[42] The well-defined 328-485 cal. yr. BP MRE occurred within a brief time of the MRE on the central Garlock fault. Both of these earthquakes occurred during an ongoing cluster of large earthquakes in the Mojave section of the ECSZ, suggesting that the faults of the ECSZ north of the Garlock fault and the Garlock fault itself may rupture together with the Mojave faults to the south during "megaclusters" that may affect large sections of the ECSZ section of the Pacific-North America plate boundary. In contrast, the welldefined $3.27-3.55 \mathrm{ka}$ Event 3 occurred during the pronounced lull in ECSZ activity from 2 to $5 \mathrm{ka}$, indicating that the PVF sometimes ruptures out of phase with the Mojave faults to the south. Interestingly, the $3.27-3.55 \mathrm{ka}$ age of our Event 3 coincides with the 3.3-3.8 ka age of the penultimate event on the Owens Valley fault [Lee et al., 2001a]. Similarly, the MRE on the Panamint Valley fault occurred within a few hundred years of the 1872 earthquake on the Owens Valley fault and the MRE on the Death Valley fault. These observations suggest the intriguing possibility that the major faults of the ECSZ north of the Garlock fault may rupture together during relatively brief clusters that occur sometimes independently of clusters on ECSZ Mojave faults to the south of the Garlock fault.

[43] The southern Panamint Valley fault earthquake ages from our trenches, together with previously published paleo-earthquake ages from the Garlock and San Andreas faults, allow us to compare patterns of regional earthquake occurrence with the results of the $\triangle \mathrm{CFF}$ modeling to assess the implications of an event on the Panamint Valley fault for the rest of southern California. Using Coulomb failure function modeling, we considered several scenarios for stress interactions between the Panamint Valley fault system and nearby faults, including the Garlock fault and Brown Mountain fault. Our modeling results indicate that a rupture along the southern Panamint Valley fault places the central Garlock fault in a state of increased Coulomb failure stress, with the potential to trigger an event along that part of the fault. This has been shown to in turn increase $\triangle \mathrm{CFF}$ stresses along the Mojave section of the San Andreas fault. Thus, although the Panamint Valley fault is removed from major population centers and thus may be considered to represent a low risk, the potential interactions between this fault and the much larger Garlock and San Andreas fault suggest that we must consider a cascade failure when assessing the threats from different faults in southern California. These results together with the earthquake dates obtained from our trench have significant implications toward assessing the probabilistic seismic hazard in southern California of a rupture on the Panamint Valley fault.

[44] Acknowledgments. This research was supported by the Southern California Earthquake Center. SCEC is funded by NSF Cooperative Agreement EAR-0529922 and USGS Cooperative Agreement 07HQAG0008. The SCEC contribution number for this paper is 1746 . Lidar data were collected by NCALM and are based on services provided by the Plate Boundary Observatory operated by UNAVCO for EarthScope and supported by the NSF (EAR-0350028 and EAR-0732947). We greatly appreciate the help of Amir Allam, Andy Tiedeman, Willy Rittase, Christine Regalla, and Alysa Young in the field, as well as helpful conversations with Eric McDonald, Ed Rhodes, and Tom Rockwell. We thank the Geothermal Program office at the China Lake Naval Weapons station, especially Andy Saban, Dan McClung, the base commander, and his staff for helping to facilitate our research. We also thank Sally McGill and Steve Personius for their constructive reviews.

\section{References}

Ambraseys, N. N. (1971), Value of historic earthquakes, Nature, 232, 375-379.

Andrew, J. E., and D. Walker (2009), Reconstructing late Cenozoic deformation in central Panamint Valley, California: Evolution of slip partitioning in the Walker Lane, Geosphere, 5, 172-198, doi:10.1130/GES00178.1.

Bacon, S. N., and S. K. Pezzopane (2007), A 25,000-year record of earthquakes on the Owens Valley fault near, Lone Pine, California: Implications for recurrence intervals, slip rates, and segmentation models, Geol. Soc. Am. Bull., 119, 823-847, doi:10.1130/B25879.1.

Bennett, R. A., B. P. Wernicke, N. A. Niemi, A. M. Friedrich, and J. I. Davis (2003), Contemporary strain rates in the northern Basin and Range province from GPS data, Tectonics, 22(2), 1008, doi:10.1029/ 2001 TC001355

Biasi, G. P., R. J. Weldon II, T. E. Fumal, and G. G. Seitz (2002), Paleoseismic event dating and the conditional probability of large earthquakes on the southern San Andreas Fault, California, Bull. Seismol. Soc. Am., 92(7), 2761-2781.

Bonilla, M. G., and J. J. Lienkaemper (1990), Visibility of fault strands in exploratory trenches and timing of rupture events, Geology, 232, 375-379.

Bryan, K., and T. K. Rockwell (1994), Recognition of non-brittle fault deformation in trench exposures: An example from the Helendale fault, in South Coast Geological Society Annual Fieldtrip Guidebook, edited by D. Murbach, pp. 253-262, South Coast Geol. Soc., Santa Ana, Calif.

Bryan, K., and T. K. Rockwell (1995), Holocene character of the Helendale fault zone, Lucerne Valley, San Bernardino County, California, Geol. Soc. Am. Abstracts with Programs, 27(5), 7.

Burchfiel, B. C., K. V. Hodges, and L. H. Royden (1987), Geology of Panamint Valley-Saline Valley pull-apart system, California-Palinspastic evidence for low-angle geometry of a Neogene range-bounding fault, J. Geophys. Res., 92(B10), 10,422-10,426.

Cichanski, M. (2000), Low-angle, range-flank faults in the Panamint, Inyo, and Slate ranges, California: Implications for recent tectonics of the Death Valley region, Geol. Soc. Am. Bull., 112(6), 871-883.

Cunningham, A. C., and J. Wallinga (2010), Selection of integration time intervals for quartz OSL decay curves, Quat. Geochronol., 5, 657-666.

Dawson, T., S. F. McGill, and T. K. Rockwell (2003), Irregular recurrence of paleoearthquakes along the central Garlock fault near El Paso Peaks, California, J. Geophys. Res., 108(B7), 2356, doi:10.1029/ 2001JB001744

Dixon, T. H., S. Robaudo, J. Lee, and M. C. Reheis (1995), Constraints on present-day Basin and Range deformation from space geodesy, Tectonics, 14(4), 755-772, doi:10.1029/95TC00931. 


\section{MCAULIFFE ET AL.: PANAMINT VALLEY FAULT PALEOEARTHQUAKES}

Dixon, T. H., M. Miller, F. Farina, H. Wang, and D. Johnson (2000), Present-day motion of the Sierra Nevada block and some tectonic implications for the Basin and Range province, North American Cordillera, Tectonics, 19(1), 1-24.

Dixon, T. H., E. Norabuena, and L. Hotaling (2003), Paleoseismology and Global Positioning System: Earthquake-cycle effects and geodetic versus geologic fault slip rates in the Eastern California shear zone, Geology, $31(1), 55-58$

Dokka, R. K., and C. J. Travis (1990a), Role of the eastern California shear zone in accommodating Pacific-North American plate motion, Geophys. Res. Lett., 17(9), 1323-1326.

Dokka, R. K., and C. J. Travis (1990b), Late Cenozoic strike-slip faulting in the Mojave Desert, California, Tectonics, 9(2), 311-340.

Dolan, J. F., and D. Wald (1998), The 1943-1953 north-central Caribbean earthquake sequence: Active tectonic setting, seismic hazards, and implications for Caribbean-North America plate motions, in Active Tectonics of the North-Central Caribbean, Geological Society of America Special Paper, vol. 326, edited by J. F. Dolan and O. Mann, pp. 143-169, Geological Society of America, Boulder, Colo.

Dolan, J. F., D. D. Bowman, and C. G. Sammis (2003), Paleoseismologic evidence for long term and long range elastic interactions, in Proceedings and Abstracts of the 2003 Southern California Earthquake Center annual meeting, XIII, 49.

Dolan, J. F., D. D. Bowman, and C. G. Sammis (2007), Long-range and long-term fault interactions in Southern California, Geology, 35(9), $855-858$.

Doser, D. I., and R. Robinson (2002), Modeling stress changes induced by earthquakes in the southern Marlborough region, South Island, New Zealand, Bull. Seismol. Soc. Am., 92, 3229-3238.

Foster, J. H. (1992), Fault development and fissuring near Twentynine Palms, California, in Engineering Geology Practice in Southern California, edited by B. W. Pipkin and R. J. Proctor, pp. 289-299, Special Publication 4, Association of Engineering Geologists, Star Publication Co., Belmont, Calif.

Frankel, K. L., et al. (2007), Cosmogenic ${ }^{10} \mathrm{Be}$ and ${ }^{36} \mathrm{Cl}$ geochronology of offset alluvial fans along the northern Death Valley fault zone: Implications for transient strain in the eastern California shear zone J. Geophys. Res., 112, B06407, doi:10.1029/2006JB004350.

Frankel, K. L., J. F. Dolan, L. A. Owen, P. Ganev, and R. C. Finkel (2011), Spatial and temporal constancy of seismic strain release along an evolving segment of the Pacific-North America plate boundary, Earth Planet. Sci. Lett., 304, 565-576.

Friedrich, A. M., B. P. Wernicke, N. A. Niemi, R. A. Bennett, and J. L. Davis (2003), Comparison of geodetic and geologic data from the Wasatch region, Utah, and implications for the spectral character of Earth deformation at periods of 10 to 10 million years, J. Geophys. Res., 108(B4), 2199 , doi:10.1029/2001JB000682

Galbraith, R. F., R. G. Roberts, G. M. Laslett, H. Yoshida, and J. M. Oleey (1999), Optical dating of single and multiple grains of quartz from Jinmium Rock Shelter, northern Australia: Part 1, experimental design and statistical model, Archaeometry, 41, 339-364.

Gan, W., J. L. Svarc, J. C. Savage, and W. H. Prescott (2000), Strain accumulation across the Eastern California Shear Zone at latitude $36^{\circ} 30^{\prime} \mathrm{N}$, J. Geophys. Res., 105, 16,229-16,236, doi:10.1029/ 2000JB900105.

Ganev, P. N., J. F. Dolan, K. Blisniuk, M. Oskin, and L. A. Owen (2010), Paleoseismic evidence for multiple Holocene earthquakes on the Calico fault: Implications for earthquake clustering in the Eastern California shear zone, Lithosphere, 2(4), 287-298.

Hanks, T. C. (1977), Earthquake stress drops, ambient tectonic stresses, and the stresses that drive plate motions, Pure Appl. Geophys., 115, 441-458.

Harris, R. A., and R. W. Simpson (1996), In the shadow of 1857-the effect of the great Ft. Tejon earthquake on subsequent earthquakes in southern California, Geophys. Res. Lett., 23, 229-232.

Hecker, S., T. E. Fumal, T. J. Powers, J. C. Hamilton, C. D. Garvin, and D. P. Schwartz (1993), Late Pleistocene-Holocene behavior of the Homestead Valley fault segment-1992 Landers, CA surface rupture, Eos Trans. $A G U, 74(43)$, Fall Meeting Suppl., 612.

Hodges, K. V., L. W. McKenna, J. Stock, J. Knapp, L. Page, K. Sternlof, D. Silverberg, G. Wüst, and J. D. Walker (1989), Evolution of extensiona basins and range topography west of Death Valley, California, Tectonics, $8(3), 453-467$

Hoffman, W., E. Kirby, E. McDonald, J. D. Walker, and J. Gosse (2009), Late Pleistocene slip rates along the Panamint Valley Fault Zone, Eastern California, Eos Trans. AGU, 90(52), Fall Meet. Suppl., Abstract T13C-1894.

Houser, C. E., and T. K. Rockwell (1996), Tectonic geomorphology and Paleoseismology of the Old Woman Springs fault, San Bernardino County, California, Geol. Soc. Am. Abstracts with Programs, 28, 76.
Kanamori, H. (1994), Mechanics of earthquakes, Annu. Rev. Earth Planet Sci., 22, 207-237.

Kanamori, H., and C. R. Allen (1986), Earthquake repeat time and average stress drop, in Earthquake Source Mechanisms, vol. 6, edited by S. Das, J. Boatwright, and C. H. Scholz, pp. 227-235, AGU, Washington, D. C

Kanamori, H., and D. L. Anderson (1975), Theoretical basis of some empirical relations in seismology, Bull. Seismol. Soc. Am., 65, 1073-1095.

Kilb, D., J. Gomberg, and P. Bodin (2002), Aftershock triggering by complete Coulomb stress changes, J. Geophys. Res., 107(B4), 2060, doi:10.1029/2001JB000202.

King, G. C. P., and M. Cocco (2001), Fault interactions by elastic stress changes: New clues from earthquake sequences, Adv. Geophys., 44, 1-38.

King, G. C. P., R. S. Stein, and J. Lin (1994), Static stress changes and the triggering of earthquakes, Bull. Seismol. Soc. Am., 84, 935-953.

Klinger, R. E. (2002), Quaternary stratigraphy and geomorphology of Northern Death Valley: Implications for tectonic activity on the northern Death Valley Fault, PhD. Dissertation, Department of Geological Sciences, University of Colorado, Boulder, Colorado

Lee, J., J. Spencer, and L. Owen (2001a), Holocene slip rates along the Owens Valley fault, California: Implications for the recent evolution of the Eastern California shear zone, Geology, 29, 819-822.

Lee, J., C. M. Rubin, and A. Calvert (2001b), Quaternary faulting history along the Deep Springs fault, California, Geol. Soc. Am. Bull., 113(7), 855-869.

Madden, C. L., C. M. Rubin, and A. Streig (2006), Holocene and Latest Pleistocene activity on the Mesquite Lake Fault near Twentynine Palms, Eastern California Shear Zone: Implications for fault interaction, Bull. Seismol. Soc. Am., 96, 1305-1320.

Madugo, C. L., J. F. Dolan, and R. D. Hartleb (2012), New paleoearthquake ages from the western Garlock fault: Implications for regional earthquake occurrence in southern California, Bull. Seismol. Soc. Am., 102, 2282-2299

Marco, S., M. Stein, and A. Agnon (1996), Long-term earthquake clustering: A 50,000-year paleoseismic record in the Dead Sea Graben, J. Geophys. Res., 106, 4103-4120.

McClusky, S. C., S. C. Bjornstad, B. H. Hager, R. W. King, B. J. Meade, M. M. Miller, F. C. Monastero, and B. J. Souter (2001), Present day kinematics of the eastern California shear zone from a geodetically constrained block model, Geophys. Res. Lett., 28, 3369-3372, doi:10.1029/2001GL013091.

McGill, S. F. (1992), Paleoseismology and neotectonics of the central and eastern Garlock fault, California, PhD. thesis, Division of Geological and Planetary Sciences, California Institute of Technology, Pasadena, California.

McGill, S. F. (1993), Latest Quaternary slip rate of the Owl Lake fault and maximum age of the latest event on the easternmost Garlock fault, $\mathrm{S}$. California, Geol. Soc. Am., Abstracts with Programs, 25, 118.

McGill, S. F., and K. Sieh (1991), Surfacial offsets on the central and eastern Garlock fault associated with prehistoric earthquakes, J. Geophys. Res., 96(B13), 21,597-21,621.

McKenzie, D., and J. Jackson (1986), A block model of distributed deformation by faulting, J. Geol. Soc. London, 143, 349-353.

Miller, M. M., D. J. Johnson, T. H. Dixon, and R. K. Dokka (2001), Refined kinematics of the Eastern California Shear Zone from GPS observations, J. Geophys. Res., 106(B2), 2245-2264.

Murray, A. S., and A. G. Wintle (2000), Luminescence dating of quartz using an improved single aliquot regenerative-dose protocol, Radiat Meas., 32, 57-73.

Murray, A. S., and A. G. Wintle (2003), The single aliquot regenerative dose protocol: Potential for improvements in reliability, Radiat. Meas., 37, 377-381.

Oldow, J. S., G. Kohler, and R. A. Donelick (1994), Late Cenozoic extensional transfer in the Walker Lane strike-slip belt, Nevada, Geology, 22, 637-640.

Oskin, M., L. Perg, D. Blumentritt, S. Mukhopadhyay, and A. Iriondo (2007), Slip rate of the Calico fault: Implications for geologic versus geodetic rate discrepancy in the Eastern California Shear Zone, J. Geophys. Res., 112, B03402, doi:10.1029/2006JB004451.

Oskin, M., L. Perg, E. Shelef, M. Strane, E. Gurney, B. Singer, and X. Zhang (2008), Elevated shear zone loading rate during an earthquake cluster in eastern California, Geology, 36(6), 507-510.

Padgett, D. C., and T. K. Rockwell (1994), Paleoseismology of the Lenwood fault, San Bernardino County, California, in Mojave Desert: South Coast Geological Society Annual Fieldtrip Guidebook, edited by D. Murbach, pp. 222-238, South Coast Geol. Soc., Santa Ana, Calif.

Prescott, J. R., and J. T. Hutton (1994), Cosmic ray contributions to dose rates for luminescence and ESR dating, Radiat. Meas., 23, 497-500

Ramsey, B. C. (2001), Development of the radiocarbon calibration program OxCal, Radiocarbon, 43(2A), 355-363. 


\section{MCAULIFFE ET AL.: PANAMINT VALLEY FAULT PALEOEARTHQUAKES}

Reheis, M. C., and T. H. Dixon (1996), Kinematics of the Eastern California shear zone: Evidence for slip transfer from Owens and Saline Valley fault zones to Fish Lake Valley fault zone, Geology, 24, 339-342.

Rockwell, T. K., S. Lindvall, M. Herzberg, D. Murbach, T. Dawson, and G. Berger (2000), Paleoseismology of the Johnson Valley, Kickapoo, and Homestead Valley faults: Clustering of earthquakes in the Eastern California Shear Zone, Bull. Seismol. Soc. Am., 90, 1200-1236.

Rollins, J. C. (2011), Coulomb static stress interactions between simulated $M>7$ earthquakes and major faults in Southern California, BS. thesis, Department of Earth Sciences, University of Southern California, California.

Rollins, J. C., G. P. Ely, and T. H. Jordan (2010) Coulomb static stress interactions between simulated $M>7$ earthquakes and major faults in Southern California, Eos Trans. $A G U$, Fall Meet. Suppl., Abstract \#S33B-2107.

Rubin, C. M., and K. Sieh (1997), Long dormancy, low slip rate, and similar slip-per-event for the Emerson fault, eastern California shear zone J. Geophys. Res., 102(B7), 15,319-15,333.

Rymer, M. J., G. G. Seitz, K. D. Weaver, A. Orgil, G. Faneros, J. C. Hamilton, and C. Goetz (2002), Geologic and Paleoseismic study of the Lavic Lake Fault at Lavic Lake Playa, Mojave Desert, Southern California, Bull. Seismol. Soc. Am., 92(4), 1577-1591.

Sammis, C. G., and J. F. Dolan (2003), Phase-locking in Coupled Non-linear Relaxation Oscillators: An Explanation for Observed Temporal and Spatial Correlation and Anti-correlation of Large Earthquakes, in Proceedings and Abstracts of the 2003 Southern California Earthquake Center annual meeting, XIII, 136.

Sammis, C. G., J. F. Dolan, and S. W. Smith (2003), Phase-locking in coupled non-linear relaxation oscillators: An explanation for observed temporal and spatial correlation and anti-correlation of large earthquakes, Eos Trans. $A G U, 84(46)$, Fall Meet. Suppl., Abstract NG32A-07.

Scharer, K. M., G. P. Biasi, and R. J. Weldon II (2011), A reevaluation of the Pallett Creek earthquake chronology based on new AMS radiocarbon dates, San Andreas fault, California, J. Geophys. Res., 116, B12111, doi:10.1029/2010JB008099.

Scholz, C. H. (2010), Large earthquake triggering, clustering, and the synchronization of faults, Bull. Seismol. Soc. Am., 3(3), 901-909.

Slate, J. L. (1999), Proceedings of Conference on Status of Geologic Research and Mapping, Death Valley National Park, Open-File Report 99-153, U.S. Geological Survey, Denver, Colo.

Stein, R. S., A. A. Barka, and J. H. Dieterich (1997), Progressive failure on the North Anatolian Fault since 1939 by earthquake stress triggering, Geophys. J. Int., 128, 594-604.

Stuiver, M., and H. Polach (1977), Discussion: Reporting of ${ }^{14} \mathrm{C}$ data, Radiocarbon, 19, 355-363.

Walker, J. D., E. Kirby, and J. E. Andrew (2005), Strain transfer and partitioning between the Panamint Valley, Searles Valley, and Ash Hill fault zones, California, Geosphere, 1, 111-118, doi:10.1130/GES00014.1.

Weldon, R. J., K. M. Scharer, T. Fumal, and G. Biasi (2004), Wrightwood and the earthquake cycle: What a long recurrence record tells us about how faults work, Geol. Soc. Am. Today, 14, 4-10.

Wintle, A. G., and A. S. Murray (2006), A review of quartz optically stimulated luminescence characteristics and their relevance in single-aliquot regenerative protocols, Radiat. Meas., 41, 369-391.

Zhang, P., M. Ellis, D. B. Slemmons, and F. Mao (1990), Right-lateral displacements and the Holocene slip rate associated with prehistoric earthquakes along the southern Panamint Valley fault zone: Implications for Southern Basin and Range tectonics and coastal California deformation, J. Geophys. Res., 95(B4), 4857-4872. 